Portland State University

PDXScholar

$1-1-2010$

\title{
Between Non-intervention and Protection: A study on the case of Darfur and the Responsibility to Protect
}

David Ryan Lucas

Portland State University

Follow this and additional works at: https://pdxscholar.library.pdx.edu/open_access_etds Let us know how access to this document benefits you.

\section{Recommended Citation}

Lucas, David Ryan, "Between Non-intervention and Protection: A study on the case of Darfur and the Responsibility to Protect" (2010). Dissertations and Theses. Paper 388.

https://doi.org/10.15760/etd.388

This Thesis is brought to you for free and open access. It has been accepted for inclusion in Dissertations and Theses by an authorized administrator of PDXScholar. Please contact us if we can make this document more accessible: pdxscholar@pdx.edu. 
Between Non-Intervention and Protection:

A Study on the Case of Darfur and the Responsibility to Protect

by

David Ryan Coleman Lucas

A thesis submitted in partial fulfillment of the requirements for the degree of

\author{
Master of Arts \\ in \\ Conflict Resolution
}

Thesis Committee:

Robert Gould, Chair

Barbara Tint

David Kinsella

Portland State University

(C) 2010 


\begin{abstract}
This thesis explores the obstacles in establishing a consistent and effective response framework for humanitarian catastrophe, and the importance of maintaining a sustained dialogue to this end. It does so by recognizing the underlying conflict between two positions: the norm of non-intervention of states into the affairs of others, and the protection of individuals caught in the middle of violent conflict. The importance of working towards a resolution of this conflict is illustrated through the case study of Darfur, where a divided international community led an insufficient response to the crisis that can ultimately be judged as a failure. Lastly, a recent attempt at reconciling the nonintervention/protection conflict is examined through the report of the Responsibility to Protect, which takes important steps in the direction of consensus, but ultimately suffers from inflated expectations regarding its scope or purpose.
\end{abstract}


Table of Contents

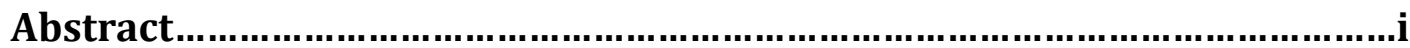

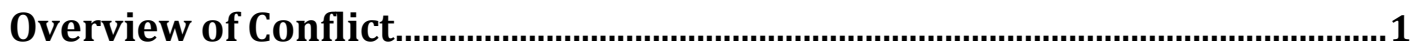

Norm of Non-Intervention ........................................................................................ 10

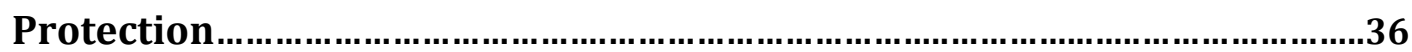

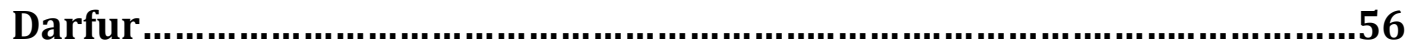

The Responsibility to

Protect.....................................................................................................88

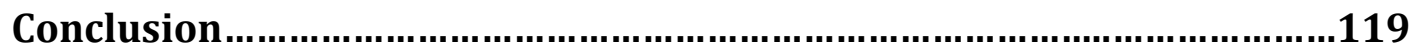

References.....................................................................................122 


\section{Overview of Conflict}

To go to war for an idea, if the war is aggressive, not defensive, is as criminal as to go to war for territory or revenue; for it is as little justifiable to force our ideas on other people, as to compel them to submit to our will in any other respect. But there assuredly are cases in which it is allowable to go to war, without having been ourselves attacked, or threatened with attack; and it is very important that nations should make up their minds in time, as to what these cases are (Mill, 1859).

There exists a dilemma, conceptually and in practice, among the methods of responding to humanitarian crises around the world. Too often, this conflict has resulted in paralysis when swift action is most needed. When the conflicting positions are the most contentious, and solutions least forthcoming, such inaction has often been the difference between life and death. The remedy will not be found in a push for action without a careful consideration of the conflict itself, nor will a careful consideration of the conflict itself summon the necessary will to take the first steps towards resolution.

If the focus in resolving this conflict were to remain on the task of saving lives, we would already be well on our way to resolving this debate. Unfortunately, this is not the case. Politics, power, ego, and greed cannot be 
ignored as key players in the debate over humanitarian conflict resolution. Still, they are not the only ones, and perhaps not even the primary ones. As the Seville Statement on Violence, a proclamation by leading researchers in psychology and neuroscience tells us, we are not doomed to violence by our nature; it is not in our genes, or latent in our subconscious (The Seville Statement on Violence, 1986). In other words, we can work towards solutions to human catastrophe; from improving systems that prevent large-scale violent outbreaks to developing consensus on how to stop them when they do, much can be done.

This thesis does not attempt to find such systems or solutions. Instead, it attempts to examine the state of the conflict at present in three stages. First, through an examination of the opposing positions of the conflict, second by examining the recent outbreak of violence in Darfur and its relation to the conflict, and third by summarizing the work of The International Committee on Intervention and State Sovereignty which has attempted to address the conflict. The conflict exists between the following positions: one, that the overall peace and stability of the world will be best served through abiding by the established norms of non-intervention and non-interference into the affairs of one state by another; and two, that overall peace and stability can be improved through more proactive, and even forceful, protection measures for individuals caught in cycles of violence when they break out. This will be referred to as the conflict between the norm of non-intervention and protection. 
Framing the debate in a dichotomy such as the conflict between nonintervention and protection requires some clarification. Non-intervention does not imply the absence of protection, nor does protection imply the use of intervention, and unless carefully described, are at risk of being condensed into sound bites arguing for the use or non-use of force. Despite their deficiencies, these terms will be used under admittedly broad strokes, as the best general description of the many complex issues underlying the debate.

The tension between the norm of non-intervention and protection is not easily navigated. On both sides, there exist compelling arguments, and important points to consider. In modifying slightly the words of Paul Ramsey (1983), that "anyone who is impressed only by the immorality and probable ineffectiveness of interventionary action should sensitize his conscience to the immorality and probable ineffectiveness of non-intervention" (p.23), I would add that those impressed only with the immorality, and ineffectiveness of non-intervention, should sensitize their conscience also to the immorality, and probable ineffectiveness of intervention as well.

Not to imply that nothing can be done, but simply that understanding and affirming the valid concerns on both sides of the non-intervention/protection conflict is absolutely necessary before any resolution can take place. Too often the conflict has led to paralysis in humanitarian crises where clear actions are needed, or the hasty, and even harmful, application of measures where clear 
criteria have not been developed. It is through an understanding of this conflict that real consensus can be fostered.

Each side of the conflict will thus be examined through the arguments and positions that inform them. The norm of non-intervention will be viewed through the perspective of non-intervention law, sovereign inviolability, and empire, and protection through that of human rights law, peacekeeping, intra-state conflict, and sovereignty as responsibility.

\section{The Legal Debate}

Resulting from two of the greatest conflicts of the $21^{\text {st }}$ century, the United Nations was created. The largest body in history for the purpose of international conflict resolution is the primary source of international law, order, and peace in the world today. It is also a source of the conflict in question. The values it aims to uphold are, at first glance, competing.

One the one hand, enshrined in the UN Charter, interpreted through the courts and largely through practice, the legal norm of non-interference from one state into the affairs of another is firmly established. On the other hand, the project of human rights informed by the universal declaration, and supported by eight human rights treaties and numerous other conventions, one of which requires action in the case of genocide to provide protections for individuals over states. Thus, when states become egregious violators of human rights, the conflict between non-intervention and protection manifests itself. 
Human rights treaties are meant to encourage compliance with basic human standards without directly becoming involved in the affairs of a state. Being essentially voluntary, states must sign and ratify the treaties, but are also able to withdraw from them. Legal pressure to join and comply with such legal treaties however can be very strong. NGOs (non-governmental organizations), civil society, and the international community can be effective in applying political pressure and coaxing states into compliance. Additionally, the UN can receive petitions of non-compliance for a number of the human rights treaties, and state parties may be called upon to present when such petitions are verified and deemed to be in violation of the treaty. While it may not dramatically alter the behaviors of a state, it does serve to expose them to the international community. Most states are, at the very least, sensitive about the reputation that they are earning in their human rights records.

\section{The Sovereignty Debate}

The role of sovereignty is arguably the most central issue in the nonintervention/protection debate. Sovereignty is the right of states to fully control their own affairs, without the interference of other states, and is the principle that allows for international relations to take place. Undermining the norm of sovereign inviolability risks opening the floodgates of interstate behavior. Unfortunately, sovereign inviolability has also allowed states that have turned violent to continue campaigns of war crimes, crimes against humanity, genocide, and ethnic cleansing, in full view of the international community, and with 
relative impunity. This challenge becomes magnified, considering that the overwhelming majority of large-scale violent conflicts since WW2 have occurred entirely within a sovereign territory, rather than between sovereign states.

The UN has tried, through the creation of peacekeeping, to reconcile the two ideals. While not defined in the UN Charter, peacekeeping has been historically a consensual activity that does not violate a states' sovereignty, and which is generally not deployed without an existing peace process or functioning cease-fire agreement. Peacekeepers generally have the permission or invitation of the government in question and do not violate the legal prohibitions on noninterference.

Peacekeeping does not impose peace from above. However after a chain of failures to deploy peacekeepers or halt ongoing killing in Rwanda, Somalia, Srebrenica, and Darfur, calls in the international community for more robust military actions in the face of atrocious conflict, particularly when the UN is unable to act, have surfaced. Generally such military actions have been given the name "humanitarian intervention."

\section{Humanitarian Intervention}

While this thesis is not about humanitarian intervention, it should be pointed out that the term itself suffers from a lack of clarity and a conceptual paradox. The term is generally used in the context of forceful military action for humanitarian goals. Clearly, forceful military action is one thing, and humanitarianism, another. While the two may perhaps be combined under 
circumstances where no better alternatives exist, the dangers of its abuse and appropriation are significant. Calls for a "right to humanitarian intervention," even when it is not sanctioned by the UN, surfaced in the 80's largely out of the formation of Doctors without Borders and popularized by its co-founder, Bernard Kouchner(Chandler, 2001).

Arguing for a right to humanitarian intervention will not assist working towards a resolution to the non-intervention/protection debate. It goes too far towards disregarding law that has been conceived in the direct aftermath of human tragedy, runs too high a risk of producing more of that which it sets out to end, and is a very difficult concept to control and contain once released from its legal chains. One example of this is when Kouchner, in his role as foreign minister of France, suggested to the Security Council the use of forceful humanitarian intervention to enter the restrictive Burmese government following a devastating cyclone in 2008 after it had been slow in allowing international assistance. The chief UN humanitarian coordinator at the time responded, "I'm not sure that invading Myanmar would be a very sensible option at this particular moment...[or that] it would be helpful to the people we're actually trying to help" (Kazmin \& Lynch, 2008).

Still, the moral conviction from which it was conceived must be salvaged. It is the same foundation that supports the idea that genocide, war crimes, crimes against humanity, and ethnic cleansing are unacceptable, and should be stopped swiftly and unequivocally when they emerge. 
Darfur

The case of Darfur will be examined in depth in this thesis. The response to the humanitarian crisis there is the latest example that an inconsistency in actions, directly resulting from the unresolved conflict between protection and non-intervention, has resulted in hundreds of thousands of deaths, and millions more war-affected. Security council resolutions against the government of Sudan were belated and insufficient when compared to the atrocities committed. Sudan also continually reminded the UN that its territorial sovereignty must not be violated by peacekeeping or intervention operations. It was supported by China in the Security Council, which initially pushed for resolutions that requested the consent of Sudan for greater UN involvement. Sudan declined the UN request for consent and did so with hardly any punitive measures applied against it. It did not acquiesce until international pressure on China led it to vote in favor on the resolution establishing a peacekeeping mission.

Responsibility to Protect

Finally, the report of the responsibility to protect (R2P) will be examined as a recent attempt to establish common ground and reframe the arguments over the non-intervention/protection debate. Noam Chomsky has described humanitarian intervention and the responsibility to protect as being "cousins"(Chomsky, 2009). As the responsibility to protect would contend however, their relation is significantly more distant. The R2P was developed with a keen awareness of the aforementioned deficiencies in humanitarian 
intervention and aimed to develop an alternative. As Kofi Annan has said, it's time to "get right away from using the term 'humanitarian' to describe military operations" (Annan, 2000).

The R2P has achieved a moderate recognition following its inception, and has even been described as an emerging legal norm. It is not, however, a panacea for addressing outbreaks of violent intrastate conflict. There remain significant obstacles to finding a balance between coercion and non-interference in addressing violent outbreaks of conflict. Among these include developing agreement between the permanent members of the Security Council to either restrict their usage of the veto, or work towards a more representative balance of power in the Security Council.

Still, it appears at present that the R2P will continue to serve as an impetus for discussion in UN. Whether or not this discussion will lead to improvements in the conflict resolution strategy for preventing outbreaks of violence, and halting them when they do occur, remains to be seen. The discussion itself, and continuing to foster conditions that allow it to take place, is a necessary one. By reframing the debate over humanitarian intervention and focusing on interests (the protection of individuals), the R2P has set out on the path towards reconciliation between the conflict of non-intervention and protection. 
Norm of non-Intervention

The UN Charter and international law

After a preamble acknowledging the universality of fundamental human rights, the preference of the UN charter for non-intervention is well established. The prohibition of force is clearly illustrated throughout the document. Article 2(4) states that: "All Members shall refrain in their international relations from the threat or use of force against the territorial integrity or political independence of any state, or in any other manner inconsistent with the Purposes of the United Nations" (Charter of the United Nations, 2006). In one of the most cited passages of the UN charter, article 2 paragraph 7, it states that, "Nothing contained in the present Charter shall authorize the United Nations to intervene in matters which are essentially within the domestic jurisdiction of any state; but this principle shall not prejudice the application of enforcement measures under Chapter VII" (Charter of the United Nations, 2006). The members referred to in the UN Charter consist of nearly every state in the world, excluding only the Vatican and Palestine, meaning that its provisions are nearly universal.

Any exceptions to the legal prohibition on the use of force may be determined by the Security Council. The Security Council is the primary body that can legally apply force "as may be necessary to maintain or restore international peace and security" (Charter of the United Nations, 2006). The 15-member world body may pass a resolution with a vote of nine, while any one of the five 
permanent members - China, France, Russia, U.K. and the U.S.-may veto a resolution, causing it to fail.

For most legal theorists who adhere to a strict interpretation of the Charter, arguments for the unauthorized use of force that are not approved by the Security Council, and are not for the purpose of self-defense, end here. Such an interpretation means that a number of military interventions unauthorized by the Security Council throughout the 90's, most obviously the NATO bombing campaign against the Federal Republic of Yugoslavia and the 2003 Iraq war, were manifestly illegal under international law.

In addition to the laws of the UN Charter, the General Assembly has twice reinforced the norm of non-intervention when political tensions during the Cold War hung precariously low over Charter law. These resolutions both reading verbatim that, "[no] State has the right to intervene, directly or indirectly, for any reason whatever, in the internal or external affairs of any other State" (U.N. General Assembly Res/20/2131, 1965; U.N. General Assembly Res/25/2625, 1970).

International Court of Justice and the case of Nicaragua

The norm of non-intervention contained in the UN Charter has also been upheld through the rulings of the International Court of Justice (ICJ), which acts as the jurisdictional arm of the United Nations. ICJ rulings are highly influential, setting precedence for interpretative questions of the Charter. The ICJ derives its 
source of international law, according to article 38 of its statute, first through "international conventions," which includes the UN charter, and second through "international custom, as evidence of a general practice accepted as law" (Statute of the International Court of Justice, 2006).

By recognizing the importance of "international custom" in the latter provision, the ICJ also recognizes that legal norms can change over time. Legal norms are the foundation and basis for the laws that are built on them. When legal norms change, laws are often amended or revised to reflect the dominant norm. For such a change to occur, however, particularly in the international arena, the practice must be widespread, and generally agreed upon. At present, rulings of the ICJ have continually recognized prohibitions on the use of force as per the UN Charter, underscoring that in the current state of legal norms, nonintervention still prevails.

The very first ruling of the court upheld the legal prohibition on force. After a number of British navy vessels were damaged by mines in the Corfu Channel of the coast of Albania, the United Kingdom set up a minesweeping operation against the wishes of the Albanian government, arguing that it had a right to intervention as an aggrieved state (Chesterman, 2001). The court ruled that:

Whatever be the present defects in international organization...[it] can only regard the alleged right of intervention as a policy of force, such as has, in the past, given rise to the most serious abuses and such as 
cannot...find a place [for it] in international law. (Corfu Channel Case as cited in Chesterman, 2001)

A later ruling, that set precedence and continues to be cited today, regarded the U.S. intervention in Nicaragua during the Reagan years. In 1984, the CIA began operations to destabilize the communist government of Nicaragua by laying mines in their ports, attacking oil installations and naval bases, and arming and training a group of rebels known as the Contra (Stein, 2004). In 1986, Nicaragua brought the matter before the ICJ. The court found the U.S to be in violation of the law through its use of force and attempt to destabilize the government through cooperation with the Contra rebel group, and decided that the U.S. must pay reparations to the Nicaraguan government.

The ruling contained important passages for the future consideration of intervention behavior: "The court cannot contemplate the creation of a new rule opening up a right of intervention by one State against another on the ground that the latter has opted for some particular ideology or political system..." it went on, "the protection of human rights...cannot be compatible with the mining of ports, the destruction of oil installations, or again with the training, arming, and equipping of the contras"(International Court of Justice, 1986). ICJ rulings, since the Nicaragua case, have upheld the norm of non-intervention, and the prohibition of force contained in article 2(4) of the UN Charter (Stein, 2004). The norm of non-intervention also forms the nucleus of other international organizations. The Organization of American States affirms, in 
article 19 of its charter, that "No State or group of States has the right to intervene, directly or indirectly, for any reason whatever, in the internal or external affairs of any other State" (Organization of American States, 1967) while in article 4 of the constitutive act of the African Union, members agree to the "prohibition of the use of force or threat to use force among Member States of the Union" and the "non-interference by any Member State in the internal affairs of another" (African Union, 2002).

Some arguments have challenged the prohibition of force in the UN Charter by claiming that under a correct interpretation, there exists a legal ground for the practice of humanitarian intervention, even if the Security Council does not approve it. Two main versions of these arguments exist.

The first claims that honest humanitarian intervention does not violate 2(4) of the charter because it does not "result in territorial conquest or political subjugation" (Tesón, 1988, p. 151). In other words, because the prohibition of force in article 2(4) is against the territorial integrity or political independence of any state, humanitarian intervention either does not threaten, or can somehow be conducted in a way that conforms to, the provisions of the Charter.

Seeking the intent of the drafters of the Charter, one can gain valuable insight from the debate on this specific passage. As Chesterman (2001) points out, this particular phrasing of 2(4) was adopted during the San Francisco Conference responding to the request of a number of smaller states to clearly reinforce, rather than weaken, the ban on the use of force or intervention in 
international relations. For Schachter (1984), to argue that any sort of military intervention fails to violate territorial integrity or political independence seems to work only if one assumes an "Orwellian interpretation" of such terms.

The second argument asserts that certain applications of force or intervention can be waged in a manner consistent with the purposes of the United Nations, and that humanitarian intervention is "in conformity of the most fundamental peremptory norms of the Charter" (Tesón, 1988, p. 151). This same reasoning was used in 1983 by the U.S. representative to the United Nations, Jeane Kirkpatrick speaking on the U.S. intervention in Grenada when she argued that there was, "ample justification for the use of force in pursuit of other values also inscribed in the Charter-freedom, democracy, peace" (Nanda, 1990, p. 498).

The response to this argument is that the section of the Charter reading "or any other manner inconsistent with the purposes of the United Nations" means that this prohibition on force should be taken in addition to other prohibitions, and should not be understood as an exception to the rule. As a U.S. delegate to the drafting committee clarified, “...the intention of the authors of the original text was to state in the broadest terms an absolute all-inclusive prohibition; the phrase 'or in any other manner' was designed to insure that there should be no loopholes" (UNCIO in Chesterman, 2001 p.49). Furthermore, the International Court of Justice has already twice rejected arguments for such a method of interpretation, including its invocation by Jeane Kirkpatrick (Holzgrefe \& Keohane, 2003). 
Ultimately the refutations of these arguments seem to reinforce further the legal norm of non-intervention, rather than challenge it. The formation of the UN following two of the deadliest wars in history was done with the firm conviction, learned through devastation and tragedy, that nations must not resort to violent force against one another. As Stein (2004) writes, "as long as the United Nations lasts, international law will never again permit the free use of force by states" (p.29).

Of course, this has not stopped states from doing so anyway. The use of force has continued and international law has been broken. In the ICJ Nicaragua ruling for example, the U.S. refused to comply with the court's order of reparations by exercising its veto power on Security Council resolutions that attempted to fulfill the edict. The United States then went on to disregard a nearunanimous General Assembly resolution urging U.S. compliance.

The U.S. reaction to the court's ruling illustrates the reality of power difference in international law. Not only does general disregard for the rule of law, as shown by the U.S., threaten the relevance and authority of the United Nations and other international legal institutions, but also the international political support for the further development of such institutions (Murphy, 1996). If one player in a global legal order is able to capriciously choose which legal rulings to obey, and which not, the entire process risks becoming a farce where those sincerely deserving of justice receive none, and cynicism or distrust prevail over working towards constructive progress and normative solutions. 
The problem is also one of consistency. If ICJ rulings have no real chance of being applied due to the threat of veto in the Security Council, should they be taken seriously? The ability for legal rulings to administer justice, whether in bringing a halt to human rights abuses, or recognizing the unlawful destabilization of democratically elected governments relies on the ability of rulings to be carried out. Through the selective enforcement of human rights, the upholding of law in the face of those who would disregard it veers dangerously close to becoming a masquerade. After all, as George W. Bush stated to the General Assembly during the lead up to the invasion of the Iraq war, "Are Security Council resolutions to be honored and enforced or cast aside without consequence?" (Bush, 2002).

While the case of Nicaragua may be a relatively clear one, the relationship of international law to larger questions of morality and the application of justice must be balanced through a host of different variables. Repeated violations of the legal prohibition on force may be the symptom of a much larger cause, while it's possible that the current laws are insufficient in addressing or enforcing nefarious behavior, and perhaps ought not be obeyed.

Glennon (2001) for example argues that law does not always lead to justice, and that there may arise situations where breaking it is preferable to arguing for a different interpretation or pushing for its repeal. Using the case of the NATO intervention in Kosovo, he argues that while the operation did violate the laws of the UN Charter, it should also be recognized that "the entirety of the 
law is not represented by the Charter alone," and that particularly in the area of military force, international law is inadequate (Glennon, 2001, p. 190).

The norm of non-intervention however is established in more than the UN Charter. Perhaps the strongest legal precedence for the non-intervention of a state into the affairs of another is that of sovereignty, specifically the norm of sovereign inviolability. Sovereign Inviolability

"It is better to recognize that we are in darkness, than to pretend that we can see the light" (Bull, 1977, p. 320).

Any discussion on the interference of one state into the affairs of another will require an examination of sovereignty. In this section, sovereignty is examined through its role as the guarantor against interference and aggression between states of different levels of power and influence, and as the foundation for, and operational principle of, international relations.

Using the definition of Hedley Bull, a sovereign state emerges from a government that is able to exercise autonomous control over a defined territory and group of people not just by right, but also in practice (Bull, 1977). It is through this formation of statehood, and the capacity for internal control that a state develops the right and practice for non-interference by external actors in its domestic affairs.

Sovereignty is thus divided into different elements, two of which are explored here: the authority of a government over domestic society (internal), 
and the assurance of the non-intervention from other sovereign states (external). Both parts are necessary to make up the whole. If a government lacks internal sovereign authority over the entire domestic society, or competing claims to the title exist, the international community cannot know whose legitimacy to recognize. Likewise, a state under the control of external interference to the point that it longer possesses autonomy over its territory, is in the most basic sense, no longer a sovereign entity (Zaum, 2007).

Sovereignty also enables the practices of diplomacy, international relations and international organization. For agreements, understandings, or relationships to take place at the international level, state representatives interact with other state representatives with the knowledge that they speak for the sovereign entity. Such representatives must also be present for participation and membership in the international community. General assembly meetings or other international forums only have one seat for each country, and decisions are not easily made lacking an agreement over who holds the sovereignty, and who represents the territory and population of a region.

From being recognized in the international community and international organizations, to being included in international agreements and participate in the worlds' international organizations, sovereignty underwrites the foundation of the global political world order. It is inseparable from the conception of the modern state, is protected, defined, and interwoven in domestic and international law, and is a bulwark against threats of hegemony and projects of 
empire (De Jouvenel, 1957; Hinsley, 1966). To eliminate or modify beyond recognition state sovereignty would "grind to a halt...the internal mechanism of the separate modern community... so much so that...its abandonment remains impossible" (Hinsley, 1966, p. 215).

While sovereignty hasn't always successfully prevented conflict or wars from breaking out, it has persisted and survived through them, and has been a feature of the post-war world orders that emerged in the aftermath. As Stephen Krasner points out, if certain features do evolve regarding the nature or scope of state authority, the organization of political life is not about to be conducted around anything else; sovereignty remains the sole viable concept (Krasner, 1999).

The emergence of the concept of Sovereignty happened in the $16^{\text {th }}$ and $17^{\text {th }}$ centuries, first through Jean Bodin's $16^{\text {th }}$ century definition, the unmitigated and unending power of a republic, where the ruler is held accountable only to God and the laws of nature (Bodin, 1992), and later by the work done by Thomas Hobbes in his 1651 treatise Leviathan. The emergence of sovereignty and its application in the treaty of Westphalia has been largely informed by evolving views on human nature.

Writing mostly on the subject of domestic, or internal sovereign authority, the Hobbesian concept was born out of a perceived chaos, and the need for order to be imposed upon it. For Hobbes the essence of human nature is derived from our connection to animal nature, and the need to surpass every other in satiating 
our appetites that will lead to our well-being. Because each person is motivated largely by self-interests, they become in competition with, and the potential enemy of, everyone else, especially when resources are scarce (Newey, 2008). The result is a "war of all, against all," or, what Hobbes identifies as a "state of nature" (Strauss, 1952).

The unmitigated anarchy present in Hobbes' state of nature leads to fear, out of which arises the desire for order and security. It is this order that the sovereign state can provide, when individuals "recognize as their real enemy is not the rival, but that terrible enemy of nature, death, who, as their common enemy, forces them to mutual understanding, trust and union..." (Strauss, 1952, p. 22). Out of this realization the internal sovereign authority is created, both to provide for domestic order, protect against outside influence, and to prevent human nature from acting out its basic nature that would lead to perpetual insecurity and war. In the international arena, human nature is simply magnified, and states peruse their interests much like individuals would, both in order to surpass every other, and to secure their own well being in a world of like states.

This concept has served as the impetus for the line of political thought that sovereignty must not submit to outside influence that would seek to weaken it, and also raises the important dynamic of power difference. Power dynamics in international relations, as realists E. H. Carr and Hans Morgenthau argue, will always influence political outcomes and international policy (Scheuerman, 2007). Attempts to qualify, divide, or weaken state sovereignty by submitting it to a set 
of criteria through treaties, laws, or organizations is, as Morgenthau writes, "contrary to logic, and politically unfeasible" (in Scheuerman, 2007, p. 259).

Carl Schmitt shared in Morgenthau's disdain for the weakening of sovereignty. Schmitt argued, like Hobbes, that a strong sovereign state is necessary to provide order, security, and stability, and that a state cannot exist legitimately without absolute authority over and above all other parts of society (Zuckert \& Zuckert, 2006). Schmitt argues that any rhetoric calling for the violation of sovereignty through the invocation of "humanity" simply wishes to cheat (Schmitt, 1996). For Schmitt those wishing to qualify sovereignty through laws or practice, even when claimed to be humanitarian, amount to "irresponsible utopianism, and/or a set of moralistic platitudes cynically invoked to cover the power bids of a superpower or of a few great powers against the weaker ones"(Cohen J. L., 2004, p. 4).

Most conceptions of sovereignty, however, recognize that state authority must be tempered, if for nothing but fulfilling the states own best interest. Machiavellian statesmanship, and totalitarian strategy are often counterproductive, and damaging to the overall goals of the state. Furthermore, the sovereign authority clearly may recognize self-imposed limitations on its power without sacrificing the larger sovereignty as a whole, or the right it has for non-intervention. As Hinsley (1966) points out, sovereignty cannot be used to justify any action the state wishes to take, but rather, is "a principle which 
maintains no more than that there must be a supreme authority within the political community if the community is to exist at all..." (P.217).

Limitations of power on a sovereign authority go further still, in that if the subjects of the sovereign no longer accept the rule of the government, the authority can change, either by the force of a revolution, or by the decision of a vote. Instead of absolute, or divine authority, Stankiewicz (1969) argues that it is the function of sovereignty that ensures security and order within a society. This function "creates the obedience that makes sovereign power and its exercise possible. Only in one sense is the sovereign separate and above the people (absolute and unlimited): no one else has more power unless he replaces him as sovereign" (Stankiewicz, 1969, p. 10).

The so-called English school of realism breaks with the strictures that Morgenthau and Schmitt placed on the weakening of state sovereignty. It still recognizes that anarchy exists, largely as a product of human nature, and that power remains the largest consideration for international relations, but it contends that there are other factors for maintaining order in world politics, and that international law and international organizations, even if they weaken state sovereignty, have played a role in providing such rules. Many of the ideas of the English school have been drawn from Hedley Bull (1977), who argues that an international society can arise from anarchy, and that order is a valuable and achievable byproduct of international institutions such as the UN or the League of Nations. 
The English school does not question the norm of sovereign inviolability as the structure of international relations, but it recognizes that achieving the common goals of all social life should be inter alia, "[the] limitation of violence resulting in death or bodily harm" (Bull, 1977, p. 18). Through recognizing the existence of order among nations, more effective political structures can be developed. Just because anarchy arises from human nature does not mean we must abandon working towards of normative moral frameworks.

Recognizing the interconnectedness among sovereign nations enables us to "behave-at least in some measure_as parts of a whole" (Bull, 1977, p. 7). The basic argument is that state actions are not performed in a vacuum, and that even actions believed to be made in a state's self interest can return to haunt them. One example of this could be a tragedy of the commons scenario where the unrestricted individual pursuit of a limited resource by all could result in the exhaustion of the resource and its availability for none(Hardin, 1968). To avoid such a disaster, and to minimize the unrest and violence that would likely follow, political entities should subject themselves to the "observance of certain rules of coexistence" in maintaining their independent sovereignty (Bull, 1977, p. 283). Still, even though international society may have a role to play in limiting violence and bodily harm, Bull concludes that it could not exist without the norm of sovereign inviolability. As such, sovereignty remains the only feasible 
foundation of world order, and the only potential starting place for achieving international consensus (Bull, 1977, p. 296).

The role and scope of these "rules of coexistence," have resulted in a split within the English school. The solidarists argue that such rules should be devised with a focus on achieving justice and upholding human rights in international society, "by leaving a margin for the use of reason and morality in the interpretation of existing rules of law" (Knudsen, 2002). Some solidarists even allow for limited use of force in the upholding and maintaining of international justice. English school pluralists disagree, and maintain that respect for established norms of nonintervention are essential. The pluralists argue that states will not agree to justice from above, particularly where it infringes upon sovereignty, beyond the fewest number of conditions necessary in maintaining international order (Sterling-Folker, 2006).

These two sides do not differ in the conviction that mass human rights violations and crimes against humanity are intolerable and deplorable, only in their beliefs of how to best prevent them. The concern in weakening sovereignty is that once it becomes subordinate to the claims of humanitarianism, the existing international rule of law and the system of international organization will collapse, or be rendered obsolete (Byers \& Chesterman, 2003). Once sovereignty must be justified through a set of criteria, the focus shifts away from the established norm of non-intervention, and those who wish to legitimize military 
action for whatever reason, are given another tool with which to do it: the invocation of humanity.

Byers \& Chesterman (2003) are concerned that by allowing exceptions to the norm of sovereign inviolability, the world will evidence more human rights violations rather than less. Diluting the strength of sovereignty will weaken a deterrent to hegemonic influence and interstate abuse. The danger is that we should drift back to a global state of affairs dominated by the use of military power as a diplomatic tool, rather than international law and organizations. The concern for undermining the norm of sovereign inviolability is summed up nicely by Glennon (2001) when he writes:

It is tempting to think that a power so benevolent as turn-of-the-century America will remain benevolent forever. Perhaps it will, but history provides room for concern that, if it is not the United States that malevolently takes advantage of a lack of rules, another emerging power will do so (p.194).

It should come as no surprise then that countries most vulnerable to coercion from powerful states are the most adamant in their defense of sovereignty. The developing world has repeatedly expressed concern over the importance of sovereign inviolability. In addition to the 114 member NonAligned Movement statement which unanimously condemned humanitarian intervention in 2000, the president of Algeria and chairperson for the Organization of African Unity noted that, "We remain extremely sensitive to any 
undermining of our sovereignty, not only because sovereignty is our last defense against the rules of an unequal world, but because we are not taking part in the decision-making process of the Security Council" (in Glennon, 2001, p. 158). Nelson Mandela, speaking on the rise of humanitarian intervention, also criticized the unauthorized use of force when he stated, "The message they're sending is that any country that fears a veto can take unilateral action. [By doing this] they're introducing chaos into international affairs: that any country can take a decision which it wants" (in Glennon, 2001, p.158).

In summary, for realists and advocates of sovereign inviolability, the dynamics of the international power imbalance combined with each state's pursuit of their own national interest, especially when the result is zero-sum, requires the law and norm be firmly established on non-intervention in order to maintain international peace and stability. The norm of sovereign inviolability ultimately protects all states, even when positions of relative power change. As we will examine in the section on intrastate conflict, however, the emerging patterns of violence in the past decades have most often been committed within a sovereign territory, flowing from the central authority to its subjects. Such outbreaks of violence required no outward breaches of sovereignty to wage brutal intrastate campaigns of war against ethnic, religious, and tribal groups. These have led to both legal and illegal responses, some of which involved a violation of sovereignty, others that worked through a peace process, obtaining consent before troops were deployed. With each intervention, 
new voices emerged on either side of the debate, calling both for the reconsideration and strengthening of sovereignty.

Some, including Finnemore (2003) have argued that not every invocation of humanity combined with the application of force and violation of sovereignty is simply "wishing to cheat." Using the case of the 1992 U.S. intervention in Somalia, Finnemore argues that as there was no established government to influence, and no economic benefit to the United States, the military intervention was not conducted in a way that would have "furthered strategic interests" (Finnemore, 2003, p. 55). The U.S. even opposed a UN proposal at the time to increase troop deployments and pacify the rogue state, citing its desire to withdraw troops as soon as possible.

When sovereign authority is achieved and wielded perniciously, as in the case of minority rule or dictatorships, the political representation may flow backwards, while sweeping authority placed in the hands of leaders with violent or abusive proclivities often has tragic consequences. Thus, one of the pressing dilemmas for the norm of sovereign inviolability comes when oppressed and under represented groups within a sovereign authority both do not consent to the authority, and simultaneously have no recourse to challenge it, or become fatally stifled in the attempt. It is when sovereignty becomes a protectorate of abusive leaders or governments, rather than as a guarantor of stability and protection, that will be further explored in a following section. 
Empire

The consideration of empire in the context of intervention goes beyond the potential for military abuse and the usage of brute force. Modern theories of empire recognize the complex interwoven nature of global power and the channels it flows through. In defining the nature of Empire, Hardt \& Negri (2000) suggest that "the fundamental principle...is that its power has no actual and localizable terrain or center [but is] distributed in networks throughout mobile and articulated mechanisms of control" (p.384).

This power need not originate from a state actor directly, but can be found in organizations that support and legitimize the underlying values and beliefs of a particular system. Organizations such as the World Bank, or the International Monetary Fund, along with multinational corporations, can be viewed as depositories of such power. Today, the physical dominance of territory is no longer necessary to siphon the benefits of cheap labor from the fringes of an empire, particularly if the empire is everywhere, and new sources of such labor are continually becoming less expensive or less regulated elsewhere. With structural, and most importantly, legal economic means of control, military coercion becomes required only when the basic underlying systems for maintaining this control are threatened.

Even through a structural conception of empire, Hardt \& Negri (2000) recognize that the United States occupies "a privileged position in the global segmentations and hierarchies of Empire" (p. 384). Indeed it would be difficult 
not to recognize the position of the U.S., with a military presence in 130 countries through a network of over 760 bases and naval fleets positioned in every major ocean in the world as being "privileged" (Department of Defense, 2008).

Madeleine Albright clarified the motivation behind the American need for pre-eminence in no uncertain terms when she explained the perpetual expansion to new markets stating that, "our own prosperity depends on having partners that are open to our exports, investments, and ideas" (Bacevich, 2002, p. 176).

During the cold war, the rhetoric which placed the U.S. as the champion of freedom, democracy, and capitalism as the bastion against the Soviet "evil empire" was matched only by its attempts at undermining, overthrowing, or weakening powers contrary to its values. During the cold war, the enterprise of protecting countries around the world from the communist threat soon became indistinguishable from the old imperial throwbacks of subjugation and exploitation, with Vietnam being a particularly vicious such example(Hardt \& Negri, 2000).

After the fall of the Soviet Union, the justifications for maintaining such a widely distributed network of military power around the world could no longer be couched in dualistic, anti-communist rhetoric. Still, after growing into its role, both economically and politically, the U.S. was not soon about to voluntarily loosen its grip (Johnson, 2004). On the contrary, the task of expanding the American imperial project by "removing barriers that inhibit the movement of 
goods, capital, ideas, and people" has been the overriding purpose of U.S. foreign policy in the last few decades (Bacevich, 2002, p. 3).

The spread of democratic capitalism has been joined at the hip with the opening of markets and free trade, all of which have been more than welcoming to the expansion of American hegemony, also commonly referred to as "leadership" (Bacevich, 2002). It appears also that, at least in the case of Iraq, the business of going to war has been folded into the PR and marketing machine that manages the folk perceptions of products and leaders. As the George W. Bush's chief of staff in 2003 told the New York Times when asked why they waited until September to build the case for war he replied, "From a marketing point of view, you don't introduce new products in August" (Bumiller, 2002).

In addition to the structural features of empire, the use of direct power, or at least the threat of it, still has its place in maintaining the "leadership" status quo. As evidenced by the enormous U.S. military dispersion, force remains an important tool of empire. One particularly pernicious document, the 2002 National Security Strategy of the United States of America unreservedly advocates a practice of preventative \& pre-emptive warfare. Its wording belies utter disregard for international law, and the U.S. strategy for maintaining global preeminence by deterring other countries from amassing forces large enough to match or challenge American dominance (Dallmayr, 2005). For Dallmayr (2005) the brazen imperial nature of such a policy even "dwarfs the ambitions of all previous empires" (p.58). 
The blatant transparency of such policies of hegemony and their application, through the invasion of Iraq, illustrates the dangers of undermining the norm of sovereign inviolability. When a nation must continually open new markets and minds to its products and ideas in the process of securing its own prosperity, the prospect of humanitarian military intervention is clearly an attractive model for doing so. In this light, the warnings of undermining the norm of sovereign inviolability become instantly clarified.

In the imperial world order, even NGOs can be appropriated for the cause. During a speech given at Yale, Colin Powell stated that NGOs and humanitarian organizations would serve as "force multipliers" during the Iraq war (Powell, 2001). The idea that aid workers are to be considered as supplementary units of force undermines the nature of their work and destroys the trust they aim to develop with local populations.

The blurring of lines between neutral humanitarian aid worker and "unit of force," can lead to the targeting of aid workers by violent groups, and the undermining of the very environment that allows them to administer assistance. Regardless of whether or not they are working for a political agenda, managing perceptions can be crucial in preventing violent backlashes. The attack on the UN compound in Baghdad in 2003 for example, which killed 17, including the former High Commissioner for Human Rights Sérgio Vieira de Mello, did so with the perception that the UN was a tool of the U.S. invasion (Frontline, 2006). 
The fusion of nation building with military operations further shows how the two are being used in tandem for imperial objectives. Provincial reconstruction teams that mix military and development objectives into one hybrid unit have seen wide usage in Iraq and Afghanistan. Their purpose is to rebuild as soon as possible immediately following attacks. As one leading general in the field boasted during his preparation for U.S. military offensive in the Marja region of Afghanistan in early 2010, “We've got a government in a box, ready to roll in" (Filkins, 2010). While the development and the creation of economic opportunity is a crucial part of reducing tensions and resolving conflicts for unstable regions, nation building done by an occupying power can hardly be described as anything other than imperial.

Any qualifying of sovereignty, or weakening of law on the prohibitions of force, run the risk of being appropriated for imperial pursuits. Today, the violation of one countries' sovereignty by another, without Security Council approval, is illegal, and will certainly result in international uproar, even if its claimed objectives do indeed have elements of humanitarian merit. But establishing an exception over time, as has been attempted by the appeal to humanitarian intervention, is in danger of developing "not just a permanent state of emergency and exception, but a permanent state of emergency and exception justified by the appeal to essential values of justice." (Hardt \& Negri, 2000, p. 18). The development of such a state would certainly benefit a neo-imperial power, particularly when such a power perceives itself as the upholder of universal 
justice. The steps between this, and the mission of spreading of civilization into the heart of darkness, fueled by moral conviction, are few indeed.

Still, this does not mean to imply that nothing can, or should be, done in the midst of violent outbreaks-even when such methods may require an application of force. The creep of imperial values must be separated as much as possible from the tasks of stopping the killing and halting the violence in areas of mass human rights violence. There are ways to regulate or direct force under international guidance and with legal oversight that can minimize the threat of neo-imperialism. It is unclear whether a truly empire-neutral framework for addressing human rights violations is conceivable particularly if empire is a structural product of globalization which is continually "rearticulating an open space and reinventing incessantly diverse and singular relations in networks across and unbounded terrain" (Hardt \& Negri, 2000, p. 182).

If, on the other hand, the dynamic of imperial power is more centralized, it would be expected to conform largely to the existence of a national interest for its expansion and conduct. Clearly, national interest rarely coincides with humanitarian interest. In the case of Somalia, the United States decided that the humanitarian merit of maintaining a (UN approved) military presence was outweighed by insufficient national interest. It also declined another opportunity, replete with moral high ground and humanitarian justification, to deploy troops and bring a halt to the Rwandan genocide. Alternately, one might interpret the 
U.S. led invasion of Iraq as a case where extraordinary national interest prompted duplicitous search for humanitarian motive. 
Protection

\section{Legal Measures}

The protection aspect of the underlying tension recognizes that any solution attempting to separate legal questions from moral ones in establishing a framework for addressing humanitarian issues is "doomed to failure" (Holzgrefe \& Keohane, 2003). To this end, the non-intervention language contained in the UN Charter has been supplemented with a number of human rights treaties established soon after the Charter's inception. These treaties have brought legal and normative recognition to the project of human rights and the protection of individuals, and provided limited methods for their enforcement.

The 1948 Universal Declaration of Human Rights (UD) seeks to protect individuals from tyrannical states, declaring that people shall be guaranteed of their "right to life, liberty and security of person" (Article 3) and that "no one shall be subjected to torture or to cruel, inhuman or degrading treatment or punishment" (Article 5).

While the UD is not legally binding and generally lacks enforcement measures, Murphy (1996) points out that it has "exercised considerable moral and political authority and is today considered by some scholars as having passed into customary international law, in whole or in part" (p.121). It has also led to a number of further human rights treaties designed to provide further oversight and legal capacity for the enforcement of its ideals. 
The Genocide Convention, created the same year as the UD requires any of the 140 contracting parties to call upon the UN and International Court of Justice to intervene for the prevention and suppression of genocide. The convention defines genocide as the:

Killing members of the group; Causing serious bodily or mental harm to members of the group; Deliberately inflicting on the group conditions of life calculated to bring about its physical destruction in whole or in part; Imposing measures intended to prevent births within the group (Convention on the Prevention and Punishment of the Crime of Genocide, 1948).

It also calls upon state parties to "undertake to prevent and punish" the crime of genocide, and that they may "call upon the competent organs of the United Nations to take such action under the Charter of the United Nations as they consider appropriate for the prevention and suppression of the act of genocide" (Convention on the Prevention and Punishment of the Crime of Genocide, 1948).

While the Genocide Convention has been cited by the ICJ in the case of Srebrenica and by the International Criminal Tribunal for Rwanda, it ultimately relies upon the auspices of the UN, and the resolutions of the Security Council for enforcement (Stein, 2004). Murphy (1996) also suggests that while the Genocide Convention does not explicitly condone the use of force to stop such crimes, there may exist a "political, if not legal, implication" (p.122) to such effect. This 
highlights the importance of correctly applying the terminology of "genocide" when making accusations in the international community, if for no other reason than to assure that such cases are met with the utmost severity and urgency.

The International Criminal Court (ICC) is a court that was established in 2002 with the signing of the Rome statute and has been ratified by 111 states, with 28 signatories not yet party to the convention (United Nations Treaty Collection, 2010). Although the court is technically independent from the UN, the Security Council may refer cases to it, and it is given the jurisdiction to issue arrest warrants and prosecute individuals suspected of committing the crimes of genocide, war crimes, and crimes against humanity. The crime of aggression is also to be included in jurisdiction of the court, however because a definition of aggression has not agreed upon, it is currently unable to prosecute individuals for this crime (Stein, 2004).

The ICC has opened investigations in four cases: Northern Uganda, the Democratic Republic of the Congo, the Central African Republic, and Darfur, and has indicted 14 individuals under charges of war crimes and crimes against humanity. Four of these are in custody and presently undergoing trial (International Criminal Court, 2010). By holding the responsible parties accountable when such acts are committed, the ICC represents new steps forward in the norm of protection. Although a number of key actors have failed to ratify the Rome Statute and become parties to the ICC, including China, Russia, and the U.S., the precedence it continues to set, most recently by issuing an arrest 
warrant for the president of Sudan in connection to crimes in Darfur, is another legal recourse for the protection of individuals.

Other measures for the enforcement of human rights have also emerged through eight human rights conventions, including the 1966 International Covenant on Economic, Social, and Cultural Rights and most recently with The Convention for the Rights of Persons with Disabilities in 2006. These treaties must be signed, ratified and actively implemented by State legislation in order to take effect. The treaties are overseen by accompanying committees who may receive complaint petitions and assign "special rapporteurs" to perform fact-finding missions at the invitation of a country to investigate alleged human rights violations and make recommendations. Treaties are thus imposed consensually upon states, which further retain the option of withdrawing at any point as parties to the convention, or prohibiting visits of a special rapporteur.

Taken together, these legal mechanisms provide a range of protections for individuals against violations of human rights, including racial discrimination, economic inequality, crimes against humanity, or war crimes. However, even for the ICC, when legal obligations for the protection of human rights conflicts with sovereign inviolability or the norm of non-intervention, the former will submit to the latter. None of the above legal devices, with the possible exception of the genocide convention, have the legal right to halt situations of open violence. As previously mentioned, the only legal entity that may do this is the Security Council. 
Peacekeeping and the Security Council

The legal focus on protection has increased exponentially in the post coldwar era. This has been most clearly evident in the Security Council, and the increase in the usage of peacekeeping operations. For the 40 years between 1946 and 1986, the Security Council passed 593 resolutions on perceived threats international peace. In the following 22 years, from 1987 to 2005, no longer faced with the cold war veto mentality, the Security Council passed 1,010 resolutions and maintained a deployment of troops in over 15 countries around the world by 2006 (Weiss, 2007).

This frenzy of resolutions was the result of a more cooperative atmosphere in the Security Council following Mikhail Gorbachev's rise to power in the Soviet Union, as well as a shift in the nature of conflict from inter state to intra state. With such a rapid and massive growth in peacekeeping, the adjustment process for the UN was slow. The organization has had to find new methods for upholding its core principles, especially when they are contradictory. As Sutterlin (2003) points out, "[t]he nature of the threats to peace and of conflict assumed characteristics for which the founders of the UN had not planned and with which the UN was not well prepared to deal" (p.7). As a result, the success of operations, when they have been launched at all, has varied.

The deployment of peacekeeping troops continues to be the primary method of addressing direct violence by the Security Council, however the characteristics of such deployments have changed greatly since the late 80 's. 
Traditional, pre-cold war peacekeeping was partially created as a compromise between the principles of non-intervention and protection, and also between the disagreements between the dominant superpowers in the Security Council (Sutterlin, 2003). It was not meant to impose peace from above, abides by the rules of impartiality, non-engagement, is lightly armed, small in number, and perhaps most importantly, requires the consent of the target state before being deployed, so as not to violate its sovereignty (Bercovitch \& Jackson, 2009). Traditional peacekeeping operates within the framework of existing political peace processes or ceasefire agreements instead of creating its own, and is not generally deployed directly in areas of open conflict.

Post cold war peacekeeping however has become significantly more robust. The criteria for what count as threats to peace and security are changing. Troop numbers have risen dramatically and are better armed, mandates authorizing the direct protection of civilians have replaced impartiality, and even the necessity of obtaining state consent before the deployment of peacekeepers has, in a few cases, been removed (Berdal \& Economides, 2007). Peacekeeping deployments in Cambodia (UNTAC), Yugoslavia (UNPROFOR), and Somalia (UNOSOM II), for example, contained significantly larger troop numbers than pre Cold War operations with around, or greater than, 20,000 troops each, were heavier armed, and were placed in situations of open violence with the goal of directly dissuading hostility between groups (Sens, 1997). 
One of the largest shifts however is illustrated by the Security Council's response to outbreaks of violence in Somalia in 1992. The response slowly grew in severity, initially following a more traditional approach through impartiality, consent, and light armament, but was extremely unsuccessful in facilitating ceasefire negotiations between warring factions and providing aid dispersal. Due to the lack of any kind of central authority in Somalia at the time, the UN found itself negotiating with the strongest-military-faction-of-the-moment in Mogadishu to obtain consent for troop deployments, who after lengthy periods of delay consented to a deployment of 500 Pakistani troops confined to the harbor and airport areas (Sutterlin, 2003).

This deployment had little to no effect in achieving regional stability, and lead to the expansion of the UNOSOM I operation by 3,000 troops, and the broadening of their mandate to provide aid worker security, disarmament activities, and ceasefire monitoring, all without obtaining-or even seekingapproval from faction leaders (Sens, 1997). The escalation of force in Somalia eventually resulted in resolution 794, where the Security Council invited the United States under Chapter VII to use "all necessary means...to establish as soon as possible a secure environment for humanitarian relief operations in Somalia" (U.N. Security Council, 1992). This nonconsensual escalation of force by the UN represented an important shift in the approach for addressing intrastate conflict through peacekeeping operations, and was the first time that Chapter VII had 
been invoked as a threat to international peace and security for an intrastate conflict.

Ultimately, following the events in Mogadishu where several American soldiers were killed and even more wounded, the U.S. withdrew its forces entirely, and the UN was forced to reconsider its objectives in Somalia. The experience had swung the pendulum back to the side of caution. Unfortunately, it did so immediately preceding the outbreak of violence in Rwanda, where no action was taken, and an estimated 800,000 were ultimately killed in the genocide (BBC, 2008). Rwanda was then followed by the massacre of over 7,000 unarmed Muslim men and boys in and around the town of Srebrenica, Bosnia in 1995, which took place despite the active presence of UN peacekeepers in the region (Simons, 2001).

When it became apparent that the Security Council would again not take action as conflict broke out between Yugoslavia and Kosovo in 1999, NAT0 launched a forceful offensive against Yugoslavia without the legitimacy of a resolution. Questions over the necessity of the bombing campaign—an obvious violation of Yugoslav sovereignty, which left Belgrade in flames-and whether the action did more harm than good, are subject to intense debate. Even so, the reluctance of the Security Council or Kofi Annan to outwardly condemn the acts has left some wondering whether or not it could perhaps become a "nascent trend" (Farer, 2003). 
This surge in intervention activity alone is enough to spark furious debates in the international community and academia regarding the nature of sovereignty, human rights, and the use of military intervention. When combined with failures such as Rwanda and Srebrenica, and the unacceptable accompanying loss of life, followed by the usage of military action outside the Security Council, the debate has reached tremendous new heights (Bellamy, 2004; Thakur, 2006).

The new intrastate nature of conflict

As we have seen, the function of sovereign inviolability is a deterrent against interstate conflicts and allows for the established framework of international order. Since the end of WW2, interstate conflict is being largely replaced by the emerging realities of intrastate conflict. It is estimated that before 194580 percent of wars were interstate, while since 1945,80 percent have been intrastate, (Sens, 1997). Of the 94 large-scale conflicts between 1989 and 2000, two were interstate in nature (Wallensteen \& Sollenberg, 2000), while in 2005 it was reported that interstate conflict made up less that 5 percent of all armed conflicts around the world (Human Security Center, 2005).

Intrastate conflicts, which are often fueled by ethnic, religious, and political tensions, have very different dynamics than interstate. The outbreak of intrastate violence is often accompanied by egregious power differences and the slaughter of unarmed civilians, while many intrastate conflicts or secessionist movements rarely take place without the involvement of other political interest 
groups, such as bordering countries or militias, potentially elongating cycles of violence.

The rise of intrastate conflict is accompanied with a rise in the number of non-combat casualties during wartime. From 1945 to 1988, civilians comprised 64 percent of wartime casualties, while by 1997, it had risen to 90 per cent (Sens, 1997). This rise in civilian casualties is accompanied by a rise in civilians fleeing the areas of violence and, either seeking refuge across a state border, or being relocated within the state as an internally displaced person.

The displacement of persons from their homes into refugee camps contributes to the complexity of intrastate conflict. In these camps, disease, squalor, and extreme privation are commonplace, while physical safety is anything but assured. Reaching 42 million at the end of 2008, including refugees, asylum seekers, and internally displaced persons (UNHCR, 2009), cross-border refugee flows also contribute to regional instability, thus posing potential threats to international peace and security.

The distinction between internally displaced persons (IDPs) and crossborder refugees is also an important one. The internally displaced have been called the "orphans of conflict," as they lack the international protection and support afforded to cross-border refugees, and remain within the domestic sovereign authority of their state (Steinberg, 2005). The mechanisms for the relocation of IDPs, if organized at all, are thus often controlled or influenced by the same groups responsible for the displacement itself. In 2008, the Internal 
Displacement Monitoring Centre placed the number of IDPs around the world at 26 million in 52 countries, while 24 countries were found responsible for new or ongoing outbreaks of conflict that actively contributed to internal displacement (International Displacement Monitoring Centre, 2008).

Because the international convention on the status of refugees does not recognize internally displaced persons, they also lack legal recourse. This combination of sovereign inviolability with intrastate conflict and internal displacement, create ideal conditions for intractable and severe human rights violations and crimes against humanity. As the Swedish Prime Minister Ingvar Carlsson observed as co-chair of the 1995 Commission on Global Governance, "to confine the concept of security exclusively to the protection of states is to ignore the interests of people in whose name sovereignty is exercised" (Jackson, 2000, p. 211).

Rwanda, Somalia, the Balkans, Sudan, Northern Uganda and Srebrenica are just a few examples where violence has been aimed largely at civilian populations, and where political solutions have remained frustratingly illusive (Bercovitch \& Jackson, 2009). While the complexities of intrastate conflict have proven unmanageable by traditional cold war peacekeeping methods, new and emerging methods are still hotly debated over their implications for sovereignty and international law.

Intrastate conflict is nothing new. What is new, is the conviction that the international community has an obligation to act in preventing it, much less that 
it could be considered a threat to international peace and security under UN law. As noted by Franck (1992), it "is no longer arguable that the United Nations cannot exert pressure against governments that oppress their own peoples" (p.85). Intrastate conflict has had a large impact on international relations and the formation of the emerging norm of protection. Since the fall of the Soviet Union and the bipolar world order, the Security Council, largely unencumbered from its former veto-induced paralysis, has shown new initiative in addressing these instances of violence through more robust forms of peacekeeping, while the feature of military humanitarian intervention, for better or worse, has become permanent on the global political landscape (Murphy, 1996).

Evolving views of sovereignty

The concept of sovereignty has undergone many transformations since its integration in 1648 Westphalia. Most recently, it has become the subject of increasing debate over the extent of these transformations, and whether or not we find ourselves in the midst of a paradigm shift (Atack, 2002).

Sovereign authority can hardly be recognized anymore (if it ever was) as absolute. Jean Bodin's $16^{\text {th }}$ century definition of the idea as "the absolute and perpetual power of a commonwealth," where the sovereign ruler is held accountable only to God and the laws of nature (Bodin, 1992), does not fit in the modern realities of eroded economic and political borders. Instead, impermeable absolute sovereign authority today appears unfeasible (Goldstein, Kahler, Keohane, \& Slaughter, 2003). 
Even the earliest applications of sovereignty applied only to European states, while peoples unrecognized by the European powers, had no recourse against hegemony, intervention, or the worst of imperial dominance (Hayman \& Williams, 2006). Further, the time between the Peace of Westphalia and the Congress of Vienna in 1815 featured the frequent practice of intervention and violation of the domestic order of states (Glennon, 2001).

Today, it is rare to find literature that does not recognize the large evolutionary steps sovereignty has taken in the past few decades (Weiss, 2007, p. 13), while some have suggested that sovereignty be regarded as a continuum, rather than a fixed, binary system (Keohane, 2003).

Maintaining the essential functions of sovereignty in international law and order will be a central project for any future framework addressing humanitarian crises. JL Cohen (2004) for example, calls for an updated international law that "requires the strengthening of supranational institutions, formal legal reform, and the creation of a global rule of law that protects both the sovereign equality of states based on a revised conception of sovereignty and human rights" (p.3). For many adherents of the emerging protection norm, the salient question today is not whether state sovereignty is, or should be, absolute, but rather if it can still act as the foundation for international order without also providing immunity for states engaged in genocide, ethnic cleansing, and crimes against humanity.

The emergence of this question is rooted in the rise of solidarism in the field of international human rights organizations. Solidarists argue that no aid 
can be politically neutral, and that in certain situations, indiscriminately distributed aid can prolong the conflict, strengthen aggressors, and even lead to increasing the magnitude of violence. As the UNHCR special envoy to the former Yugoslavia explained, "If by neutrality, one means to help all victims without discrimination...that is correct...but if neutrality means not to take sides, not even in favor of the victims, that would be a wrong interpretation: we chose to be on the side of the victims" (Cohen \& Deng, 1998, p. 269). The solidarist position is contrasted with that of classicism, which advocates political neutrality in conflict, as long as it allows for the access and distribution of aid to suffering populations.

Some NGOs have taken sides in the solidarist/classicist divide. Médecins Sans Frontières/Doctors Without Borders (MSF) for example was formed as a consciously solidarist organization, breaking with the classicist, impartial approach of NGOs, such as the International Committee of the Red Cross (ICRC). MSF was established by former ICRC members who believed in actively denouncing the actions of a government when they contributed to, or were responsible for, violent conflict. Upon accepting the Nobel Prize on behalf of MSF in 1999, James Orbinski stated that, "silence has long been confused with neutrality, and has been presented as a necessary condition for humanitarian action...we are not sure that words can always save lives, but we know that silence can certainly kill" (Orbinski, 1999). MSF has even been credited by some with popularizing the notion of a "right to intervention," even before "humanitarian" was added to the phrase (Chandler, 2001). 
The founding of MSF in 1977, anticipated the direction that the debate over humanitarian practice was headed. A growing number of humanitarian workers were beginning to criticize the classicist practices of aid distribution, without addressing the underlying causes of the conflict. One opinion writer for the New York Times criticized the distribution of food aid to victims of humanitarian crises without also providing security, or addressing direct sources of violence, as producing the "well-fed dead" (New York Times, 1992). The norm of non-interference in internal state affairs held fast as internal displacement exploded throughout the 90's and IDP camps became staging grounds for violent attacks and warlordism (Fiona, 2002). As the Secretary-General of the Organization of African Unity, Salim Ahmed Salim noted, non-interference was quickly reaching "absurd proportions" in Africa (Cohen \& Deng, 1998, p. 215). The search for solutions was beginning.

In 1993, Sudanese diplomat Francis Deng was appointed by the Secretary General as the UN special representative on internally displaced persons. Throughout his appointment, Deng has sought to find solutions for IDPs, informed largely through a volume of case studies examining the causes and problems of internal displacement. Deng and his colleague Roberta Cohen recognized that the norm of sovereign inviolability was among the largest factors preventing the international community from providing security and aid to persons trapped in camps within their own countries. 
In their recommendations Cohen \& Deng call for host of measures that can be taken for the internally displaced, including strengthening the role of NGOs and national institutions, coordinating and unifying UN agencies, and altering the notion of sovereignty, so that it includes the element of responsibility for the protection and well-being for the citizens of a state (Cohen \& Deng, 1998). They write:

Sovereignty cannot be used as a justification for the mistreatment of populations. When governments fail to meet their obligations to beleaguered populations, such as the internally displaced, they are expected to request outside assistance to help them fulfill their responsibilities. Should they refuse to accept such assistance, the international community can and should assert its concern, and step in when the government has failed to discharge its responsibility (Cohen \& Deng, 1998, p. 276).

Their work has accompanied the call for an opening of a new debate over the function of sovereignty and its role in situations of state-sponsored abuse.

Recognizing the evolutionary steps of sovereignty, Boutros Boutros-Ghali announced in the 1992 Agenda for Peace report that, "Respect for...fundamental sovereignty and integrity are crucial to any common international progress. The time of absolute and exclusive sovereignty, however, has passed; its theory was never matched by reality" (Report of the Secretary General, 1992).

The 2004 UN Panel on Threats Challenge and Change also noted that: 
Whatever perceptions may have prevailed when the Westphalian system first gave rise to the notion of State sovereignty, today it clearly carries with it the obligation of a State to protect the welfare of its own peoples and meet its obligations to the wider international community (High-Level Panel on Threats, Challenges and Change, 2004).

Enshrined in its charter document, the African Union (AU) also recognizes that sovereignty should not trump the ability for protection. While it affirms in its charter both the respect for the sovereignty of its member states, it reserves the right in paragraph 4(h) "to intervene in a Member State pursuant to a decision of the Assembly in respect of grave circumstances, namely war crimes, genocide and crimes against humanity" (African Union, 2002). This means also that it has reserved the right to do so, independent of the Security Council.

Some have argued that the emergence of the protection norm is not unprecedented in the larger historical context of intervention practice. Finnemore (2003) argues that the changing nature of intervention has accompanied the changing nature of western concepts of humanity. As the understanding of human equality has changed under the progress of emancipation and the liberalization of values, so too have the views of who has moral standing to be rescued in a state of crisis. Finnemore points out that people who would have previously disappeared under the radar of moral outrage are now being seen as equally deserving of protection as the "white Christians" were in the $19^{\text {th }}$ century, while under siege from Ottoman influence (Finnemore, 2003). 
In illustrating the relatively recent recognition of the equality of races, sexes, and classes, as equally deserving of humanitarian attention, the normative emergence of protection is, perhaps, not as surprising. This might suggest that humanitarian intervention is nothing new, but rather the judgment of who counts as human that is emergent.

It is clear that the features of sovereignty have been changing, and that the recognition of this change is widespread, but where are the lines to be drawn? Some have argued that not only does a humanitarian exception to sovereignty exist, but that the exception should also extend to preventing the spread of weapons of mass destruction. Feinstein \& Slaughter (2004) claim that a "duty to prevent" should exist to combat the threat of nuclear proliferation, and that "like intervention for humanitarian purposes, international action to counter WMD proliferation can take the form of diplomatic pressure or incentives, economic measures, or coercive action" (p.145). The proponents of emerging views of sovereignty also got a bit more than they asked for in 2003, when the U.S. led invasion of Iraq began using humanitarian justifications to justify its illegal aggression.

As evidenced by this abuse, and the calls for subjecting sovereignty to a whole host of different criteria, what exactly the nature of sovereignty is changing into remains unclear. Its continued success in allowing violent governments to dictate the terms of international assistance to suffering populations and allowing such governments to evade being held accountable for 
their actions, suggest that the changes to sovereignty have further to go before matching the rhetoric.

What remains is an opportunity for either steps towards consensus within the UN framework, or the continued undermining of UN authority. Even if developing international consensus for legitimate uses of force outside UN resolutions weren't such a daunting task, some question the efficacy of this when states already have no shortage of ethical rhetorical instruments for justifying their determined course of action (Bellamy, International Affairs, 2008). Either way, military intervention, outside Security Council resolutions, will continue to occur. Except that is, when they don't. On the one hand, we can't assume that future military actions outside of Security Council approval will remain "illegal, but legitimate," as the Independent International Commission on Kosovo ultimately decided that the NATO intervention was. On the other, we should not expect that they will happen at all when they are most needed, legally or otherwise.

Kofi Annan highlighted this problem in an address to the General Assembly:

While the genocide in Rwanda will define for our generation the consequences of inaction in the face of mass murder, the more recent conflict in Kosovo has prompted important questions about the consequences of action in the absence of complete unity on the part of the international community (U.N. Press Release, 1999). 
A year later, Annan stated, "In essence the problem is one of responsibility: in circumstances in which universally accepted human rights are being violated on a massive scale, we have a responsibility to act" (U.N. General Assembly, 55th Sess., 2000).

As the example of Darfur will show, no clear consensus has been reached. Not on the emerging definitions of sovereignty, not on the how, when, and why of intervention behavior, not even on the present landscape of legal norms. Nevertheless, the task of working towards a set of response criteria should not be abandoned. Many diplomatic measures exist in the toolbox of international relations and conflict resolution that most parties can agree on, and it's by building on this common ground, that the greatest chance for consensus exists.

Ultimately, even assuming agreement can be reached over the insufficiencies of sovereignty inviolability for the sake of individual protection, many questions remain. What cases would be applicable for a sovereign exception and who would decide when such action has crossed the threshold? Finally, what actions can be taken, when the Security Council does not act, and how can these be separated from the creep of neo imperialism?

These questions do not lend themselves to simple answers, nor will any response framework be able to satisfy the positions of all parties. Regardless, the importance of mapping out the conflict, so that it can be navigated, is clear-as the following case intends to show. 
Darfur

Located in western Sudan, Darfur is a sparsely populated region covering an area roughly the size of France with an estimated population (2006) of 6-6.5 Million (OCHA, 2008). The population is a mix of nomadic, sedentary, Arab, African, and Afro-Arab groups, nearly all of which are Muslim (O'Fahey, 2008). "Dar" with historical connotations of "home" or "land of" has its roots in an ancient tribal system of land usage and ownership that allows the right to settlement and passage of an area, while the Fur are a sedentary tribal group. Darfur thus can be translated literally as "home of the Fur." During the seventeenth century, the Fur ruled over the region through a sultanate that functioned as a centralized authority with bureaucratic and military systems. The Fur were among the land (Dar) holders who sustained themselves through farming, while other tribal groups in the region would share grazing areas with the farming groups.

Other than slowly dismantling the Sultanate and most of the tribal land management, British rule in the early $20^{\text {th }}$ century largely adopted a policy of "non-interference" in Darfur (De Waal, 2007, p. 73). Leaving much of the systems of eldership and tribal conflict resolution in place, they neglected to invest in infrastructure or economic development, governing under the principle of "indirect rule," leaving the region largely as it had existed during the previous centuries (O'Fahey, 2008, p. 299). Following independence, the post-colonial government of an independent Sudan made few policy changes in Darfur. Despite 
a rapid growth in population of around 5 million, Khartoum, which never fully established its governing authority in the region during the 50's and 60's, made little investment in Darfur other that what O’Fahey (2008) has called "brutal and rapid urbanization" (p.301).

While the overwhelming majority of Darfurians share an Islamic faith, this faith underwent changes through the 50's and 60's from a traditionally more tolerant, Sufi form of Islam, to a more political practice. Cultural changes, including what Paul Doornbos has identified as the "Sudanification" of tribal groups in Darfur accompanied a paucity of government services and neglect (Doornbos, 1988). In 1995, the government broke Darfur into three states which was largely responsible for weakening or undermining the social fabric of the region, and was considered by many, within the Fur tribe, as being done to divide and erode their chances at governing (Abdul-Jalil, Mohammed, \& Yousuf, 2007). Although it has been invoked in the conflict, ethnic differences between Darfurians are not always easy to identify. Skin color and religion cannot account for differences, while cultural heritage, and even language (Arabic) is often shared. Instead, "the basis for the cleavage is the claim to an Arab identity that has less to do with the above criteria that it does with often-fictional patrilineal lineages that lead back to mythical Arab forbearers. There may be little, if any, historical accuracy to these constructs. But to those who invoke them, they are fact and truth" (Tubiana, 2007, p. 70). For the sake of simplification, "Arab" and 
"African" will be used from here on to identify differences between group identities with the important caveat that external differences are often very few. Civil War

The events leading to the 2003 eruption of violence in Darfur have roots in the tumultuous past of Sudan. The north/south civil war, which had been raging since 1983 and is responsible for over 1.9 million deaths, with well as over 4 million forced to flee their homes (Iyob \& Khadiagala, 2006) had deepened tribal, political, and regional divisions during the lead up to the Darfur conflict. It also intensified the fears the ruling elite in Khartoum had about losing territory to emerging insurgent movements around the country.

The civil war is relevant to Darfur in three main points. First, the government's response to the insurgency in the south shares similarities to the counterinsurgency in Darfur. Second, the work of the main rebel group in the south informed, assisted, and nurtured rebels in Darfur with both political ideology and direction. Third, while the international community was focused on the north/south peace process in Sudan, it was often at the expense of Darfur. Among Khartoum's preferred methods for dealing with civil unrest, and one that will become immediately relevant in looking at the conflict in Darfur, is the masterful exploitation of existing tribal tensions by distributing weapons to the historic rivals of tribal groups the government hopes to suppress, and to incite violence between them. This tactic was honed during the civil war and 
perfected in Darfur. The nature of such a strategy is that the violence quickly develops a dynamic of its own.

Northern Sudan, home of the capital Khartoum, is predominantly made up of self-identifying Arab, Muslim. In Khartoum state power is consolidated by a handful of elites struggling to hold onto Arab minority rule in a largely African nation. The post-colonial power balance has hardly respected the diversity in Sudan, with some arguing that "since independence all governments in Khartoum have totally neglected the economic, political, and cultural interests of the nonMuslim and non-Arab natives of southern Sudan" (Kebbede, 1999, p. 7)

In the south, self-identifying "African," non-religious, animistic, or Christian groups have suffered from the same kind of political isolation and ethnically charged discrimination as the Darfurians in the west. This isolation has been intensified by statewide reforms imposing a requirement on all English speaking Universities around the country to perform their education in Arabic, compulsory courses in Qur'an studies, the separation of the sexes, and the mandatory wearing of a veil for female students. University professors who did not fit into the Islamic reforms were summarily dismissed, and in 1983 Shari'a law was imposed on the whole of Sudan(Kebbede, 1999).

The Sudan People's Liberation Movement/Army (SPLM/A), a predominately Christian, African insurgent group, under the leadership of John Garang, was the driving force in the push for southern autonomy and equality. Throughout the civil war, the SPLA were relatively successful at keeping pressure 
on the government until they agreed to power sharing concessions. The Comprehensive Peace Agreement (CPA), signed in 2005, was the result of intermittent peace efforts afforded by the international community. On paper, it recognized the southern negotiators call for political autonomy and equal recognition, scheduling a vote for independence at a later date.

The North-South peace process influenced the response to Darfur in that until early 2004, the international community was so focused on it, that other matters: widespread deaths and the destruction of villages, for example, became secondary. There had been a long and drawn out debate within the international community over how the peace processes should be sequenced. So many resources had already been devoted to the negotiations in Naivasha that there was reluctance to engage in Darfur, out of fear that pressuring the government would jeopardize the progress made in the north-south negotiations. Some have cited the push for north/south peace as the reason why Darfur had been neglected for so long and why the situation there was allowed to continue (Feinstein International Famine Center, 2005).

Darfur Rebel Insurgency

Hassan Al-Turabi was a religious and political figure in Sudan and a founding member in the 1980s of the political party the National Islamic Front (NIF). The NIF successfully executed a coup d'état in 1989, resulting in a government power structure made up of complicated power-sharing agreements between Al-Turabi and his highest-ranking general, Omar Al-Bashir (Kebbede, 
1999). The revolution brought sweeping Islamic reforms throughout the country, including the banning of singing and dancing, and severe limitations on women's freedoms. In 1993, Omar Al-Bashir's appointed himself president, while Al-Turabi continued to serving in various positions for the next years, including as speaker of the house (Flint \& De Waal, 2005).

In 1999 a lengthy power struggle between the NIF's leadership broke out, particularly between Al-Bashir and Al-Turabi. The result was the dissolution of parliament by President Al-Bashir, the suspension of the constitution, a declaration of a state of emergency, and the banishing of Al-Turabi from the government in December 1999 (Daly, 2007). Al-Bashir was slowly consolidating state power around himself.

The new power balance in the government was able to make progress in the north-south peace talks, but as these slowly moved forward, levels of violence in Darfur continued to rise. Under the NIF government, Darfur's unsolved problems continued deteriorating; issues of land, water, and being used as a staging ground for Libyan troops launching attacks into Chad meant that intertribal tensions were high, and conflict recurrent (Flint \& De Waal, 2005). When tensions did give way to violence, it was often between nomadic Arab Muslims and sedentary African Muslims of Darfur. As Mamdani (2009) points out, nobody seemed to be in control, and "no conflict resolution mechanism seemed to be in place" (p.249). 
Much of the violence had taken the form of nomadic raiders on sedentary groups. As a result, many of the sedentary tribal groups had already begun to form militias for protection, while certain ethnic tribes, including the Zaghawa and the Fur, chose to form alliances (Mamdani, 2009). M.W. Daily points out that, "Each of the several major groups that would eventually form the nucleus of revolt, Fur, Zaghawa, and Masalit, was the focus of ever-increasing violence from Arab militias, and pleas for government protection fell on deaf ears or were even punished" (Daly, 2007, p. 267).

Following the unrest and overall instability throughout the 80 's and 90 's, and an instance in 2001 involving Arab raiders which left over 125 people in Abu Gamra dead, tribal militia groups that were previously more concerned with security began airing their grievances with the government in Khartoum for not stopping the raider attacks (Daly, 2007, p. 268). These militia groups become increasingly centralized and political as the attacks continued. The seeds of insurgency were sprouting among the three main tribes of the region, and in 2000 , the first rebel military bases were established and training began towards a formal counter insurgency (Flint \& De Waal, 2005).

Meanwhile, stripped of political legitimacy and government influence, $\mathrm{Al}-$ Turabi created a new political party, the Popular Congress Party (PCP), and, in a move demonstrating contempt for Al-Bashir, signed a "memorandum of understanding" with the SPLA in February of 2001, strategically befriending the enemy of his enemy (Daly, 2007, p. 271). Al-Turabi's PCP hoped to further incite 
violent resistance against Al-Bashir's government through forging unity between the southern civil war forces of the SPLA/M and the Darfur insurgency groups (Mamdani, 2009, p. 239). In June of 2001, the SPLA/M attempted to push their way northwest to join with nascent insurgency forces in Darfur, but were cut off by government troops, with the resulting battle displacing more than 30,000 persons who fled mostly on foot (Prunier, 2008, p. 87).

While the resistance groups were still largely nebulous at this point, the largest of them was known as the Darfur Liberation Front (DLF), and launched its first attack on the government in February 2002 destroying a government post near Nyala (Daly, 2007). Through failed attempts at mediation and continued military losses against the growing insurgency, the government began searching for new methods to respond to the attacks and the attempts of the SPLA to join rebel groups in Darfur. Turning to a method that had already proved effective in the South, the GoS increased their arming and unleashing of Arab raiders. In April of 2002 in the town of Shoba, the raiders killed 17 people and burned 600 houses to the ground; they also stole 2,000 heads of cattle, removing a fundamental part of the villages' livelihood, and thus discouraging them to return (Prunier, 2008, p. 88).

In early 2002, Al-Turabi delivered a flow of weapons to the insurgent groups hoping to develop an influence over the rebels, and with it, a modicum of political capital (Prunier, 2008, p. 88). As the raider attacks continued, the DLF continued its training and acquisition of weapons and vehicles. On March $16^{\text {th }}$ 
2003, through continued cooperation among rebel groups, a political declaration was released and a new united resistance front emerged under the name Sudanese Liberation Movement/Front (SLM/A). The manifesto which shared many similarities with the declaration of the SPLM/A, denounced generations of oppression and called upon a:

United democratic Sudan...predicated on full acknowledgment of Sudan's ethnic, cultural, social, and political diversity. [On] an economy and political system that address the uneven development and marginalization that have plagued the country since independence...religion and politics...must be kept in their respective domains, with religion belonging to the personal domain and the state in the public domain. The SLM/A firmly opposes the Khartoum Government's policies of using some Arab tribes to achieve its hegemonic devices that are detrimental both to Arabs and non-Arabs (Sudanese Liberation Movement, 2003). Emboldened with political direction, the SLM/A continued launching attacks on government-controlled positions in the west of Sudan around the same time that the north-south peace process was beginning to gain traction. On the $26^{\text {th }}$ of February 2003 , around 300 rebels operating with 30 so-called 'technicals' (Toyota Land cruisers rigged with top-mounted machine guns) attacked a government garrison in the town of Gulu, killing nearly 200 government soldiers and disbanding the garrison, causing the troops to flee (Prunier, 2008, p. 92). 
The attacks forced the Government to acknowledge the rapidly escalating conflict in Darfur, while also maintaining a stable façade for the international community that everything was under control for the continuation of the peace talks in Naivasha. A press release was issued the day after the Guli attack stating that, "These people are not rebels but bandits; [they] will not jeopardize the peace process" (in Prunier, 2008, p. 95).

A second rebel group was forming around the same time in Darfur that had originally been supportive of the NIF after it seized power, but quickly became disillusioned with continued government neglect and its continued policies of favoritism. Calling themselves the Justice and Equality Movement (JEM), the group is associated with documenting the history of minority rule in Sudan and the tactics of political exclusion through the publication of a volume, titled The Black Book: Imbalance of Power and Wealth in the Sudan. The book was published and distributed around the country in 2000 and 2002, and statistically documented the severe imbalance of political representation within the government, illustrating how a certain northern Arab tribal group had been able to dominate the rest of the country through coercion and political subterfuge (Seekers of Truth and Justice, 2004).

Even while the majority of educated Sudanese were already well aware of such government discrimination and policies of selective representation, The Black Book brought together different elements of the Darfur resistance both within the SLM/A and the JEM, strengthening their resolve and justifying their 
cause, while also managing to further provoke an already frantic government, which hastened its arming and cooperation with Arab raider groups (Daly, 2007, p.276).

While the two resistance movements both shared anti-government sentiments and recognized the need for better representation and equality in Darfur, they differed in their approach and ideology. The SLM/A was composed largely of secular, multiethnic groups advocating for the reorganization of the Sudanese government in favor of a fairer distribution of power and economic opportunity, while the JEM was formed as a neo-Islamist revival movement calling for a reconsideration of Darfur's position in a unified Sudan under shari'a law (Iyob \& Khadiagala, 2006). It was also the JEM that Al-Turabi was drawn towards in his efforts to push back against the Al-Bashir government.

The SLM/A and JEM continued making demands of the government for economic equality, development projects, political recognition, and to stop being called "armed bandits" (Mamdani, 2009). Continuing with their early military successes, the rebels launched an attack on April 25 2003 targeting both Nyala and al-Fashir, and resulted in their occupying the airport, destroying airplanes and gunships, and capturing the commander of an air force base (Flint, 2007). The insurgency attacks continued into late May, where rebels seized the city of Kutum and killed around 500 Sudanese soldiers in and around the garrison, followed by an attack on Tinay resulting in around 250 government troop casualties (Prunier, 2008). 
Having won thirty-four of their thirty-eight skirmishes during the middle of 2003 (O'Fahey, 2008), the insurgency had created disarray within the GoS. Recognizing their need to appear in control of their country during the north-south peace process, the NIF government "became instantly determined to avenge the insults" (Flint, 2007, p. 152). Not long after the attacks on Kutum, a group of 150 Darfur notables in Khartoum drafted a plea to the government, which called for the opening of political dialogue with the rebellion, a ceasefire, the freeing of Darfur political prisoners, and the organization of humanitarian aid delivery before the start of the rainy season. Indignant, the government responded by stepping up arrests of suspected rebel supporters in Khartoum, declared a state of emergency in Darfur, and threw its full weight behind the Arab raider solution, or what Flint \& de Waal have termed "counterinsurgency on the cheap" (Flint \& De Waal, 2005).

\section{The Government Response and Escalation of Violence}

"Janjaweed" is a term used to describe an armed bandit group who were recruited heavily, but not exclusively from nomadic Arab camel herders from the north of Darfur and Chad (Haggar, 2007).

These nomadic groups have been particularly susceptible in reverting to banditry as they have been largely excluded from land ownership rights in Darfur, and, as such, were largely marginalized in the region. An example of this can be seen when the group calling itself the Committee of the Arab Gathering sent a letter to the prime minister of Sudan in 1987 warning against the 
consequences of Arab discrimination in Darfur. The group claimed that Arab tribes of Darfur lacked fair representation and felt like they were subjects, rather than citizens. The group claimed that Arabs were responsible for creating the Darfur civilization, and requested more involvement in regional and central government, warning that failing this, "things may get out of the hands of wise people and... a catastrophe with dire consequence, may take place" (Arab Gathering Letter, 1987).

The tensions were compounded with the process of desertification that has been taking place in Darfur since the 80's. The drought, brought on by both rapid population increases, as well as natural environmental changes, has created water shortages and constricted grazing areas for nomadic groups, disrupting their traditional migration patterns and interfering with the region's specific and time honored strategies for survival. As this pushed the nomads closer to sedentary farmland, tensions over the limited grazing areas, fresh water, and fertile soil have made "land, and who owns it...a deadly issue in Darfur" (O'Fahey, 2008, p. 301).

It was in this context of desperation, combined with a steady flow of weapons and the ideology of Arab supremacy rooted in propaganda from Gaddafi's Libya, that nomad groups so readily resorted to banditry, while genuine grievances made the Janjaweed an ideal tool for government counterinsurgency efforts (Haggar, 2007). The tensions were illustrated in one tape-recorded meeting where a future Janjaweed commander was speaking with a militia leader 
in Chad, thanking them for "providing his tribe in Sudan with the necessary weapons and ammunition to exterminate the African tribes in Darfur" (Kiernan, 2007, p. 595).

With a poorly trained and thinly spread military, the government was finding itself outmaneuvered and on the losing end of what was quickly becoming a second civil war. Flint \& de Waal point out that at the beginning, the government's usage of tribal militias as being:

Purely opportunistic: there they were, they had fighting skills and they allowed the government to conserve its own, overstretched resources...but as time went on the militias...gave the government the cover of 'age-old tribal conflict', enabling it to deny there was a civil war at all (Flint \& De Waal, 2005, p. 57).

The U.S. special envoy to Sudan Andrew Natsios described the use of the Janjaweed to the Senate Foreign Relations Committee:

The Government of Sudan is using strategies against Darfur that were first used against the south for many years. By manipulating pre-existing tribal divisions, the Government has played a major role in splintering the opposition movements into factions and has attempted to buy off one small group at a time rather than pursuing a broader peace through transparent negotiation with all parties (Natsios, 2007).

On the $25^{\text {th }}$ of July 2003 the Sudanese newspaper Al-Adwaa reported that the Government had exhausted its diplomatic efforts in resolving the insurgency 
in Darfur, and that the conflict must now be resolved by military means (in Prunier, 2008). Because the military had already proven itself inept, the government was really referring here to the Janjaweed. In the process of building up the raiders to an effective counterinsurgent group, criminals who could be counted on for their ruthlessness were released from prison to join and lead the militia operations (Daly, 2007, p. 282). Through an active recruitment process, the government sought to add members by arming and remunerating the Janjaweed, paying a salary which varied depending on whether they could read or write, and if they owned a horse or camel (Prunier, 2008).

The Janjaweed increasingly came to resemble a group of pirates, giving themselves names such as the "angel of death," and were often less interested in fighting the rebels than they were in making "surprise attacks on civilians in their towns and villages" in order to rape, pillage, and collect loot (Daly, 2007, p. 283). This could hardly have been unexpected, as the Janjaweed were encouraged and motivated by the government with promises of free reign over villages once they were destroyed. In interviews, Janjaweed members confessed that they had been instructed to "enter the village first and burn everything, and afterwards take 'what you like'" (Human Rights Watch, 2005, p. 20).

Despite the governments' early attempts to do so, its connections to the Janaweed cannot be denied. Human Rights Watch reported that "the record of the Sudanese military in Darfur demonstrates that the crimes against civilians were part of a policy that can only have been created by the Sudanese political 
and military leadership in Khartoum" (Human Rights Watch, 2005, p. 34). The report goes on to cite an $\mathrm{AU}$ observer on the ground who observed that in nearly every attack, helicopter gunships were present, along with transports which performed reconnaissance, dropped metal drums full of explosives, and directed fire (Human Rights Watch, 2005). As noted by one villager, "We know the Arabs. They don't have planes; they have cows! Only the government has planes!" (Flint \& De Waal, 2005, p. 107).

Throughout 2003, the violence in western Sudan from both sides continued to escalate. Prunier (2008) describes some of the initial bombing attacks carried out by the government and Janjaweed against villages in Darfur:

First aircraft would come over a village, as if smelling the target, and then return to release their bombs. The raids were carried out by Russian-built four-engine Antonov An-12s, which are not bombers but transports. They have no bomb bays or aiming mechanisms, and the "bombs" they dropped were old oil drums stuffed with a mixture of explosives and metallic debris. These were rolled on the floor of the transport and dropped out of the rear ramp, which was kept open during the flight. The result was primitive free falling cluster bombs, which were completely useless from a military point of view, since they could not be aimed, but had a deadly efficiency against fixed civilian targets. As any combatant with a minimum of training could easily duck them, they were terror weapons, aimed solely at civilians. After the Antonovs had finished their grisly job, combat 
helicopters and/or MiG fighter-bombers would come, machinegunning and firing rockets at any large targets such as a school or a warehouse which might still be standing. Utter destruction was clearly programmed. When the air attacks were over the Janjaweed would arrive, either by themselves or in the company or regular Army units. The militiamen would be mounted on horses and camels and often be accompanied by others riding in "technicals". They would surround the village and what followed would vary. In the "hard" pattern they would cordon off the place, loot personal belongings, rape the girls and women, steal the cattle and kill the donkeys. Then they would burn the houses and shoot all those who could not run away. Small children, being light, were often tossed back in the burning houses (p.100). Flint \& De Waal (2005) through extensive interviews have further documented bombings, as well as summary executions of suspected SLA leaders, who were dragged from their villages and killed in the hundreds. The majority of the violence coming from the Janjaweed and Government counterinsurgency was directed towards the Fur, Masalit, and Zaghawa tribal groups. The patterns of violence were remarkably uniform. They included the burning of huts, food, and mosques, the stealing of cattle, mass killings, rape, and the poisoning of water wells with corpses to render villages beyond the possibility of return, depopulate the land, and humiliate the population (Flint \& De Waal, 2005). Attacks were often combined with abusive racial epithets calling the villagers slaves, and 
claiming Arab ownership of the land (Daly, 2007). When pushed to disarm the Janjaweed, the GoS would either invite the AU to watch a public disarmament ceremony on one day, and hand them back the next, or simply merge the militia members into the government security and defense forces (Human Rights Watch, 2005; Flint \& De Waal, 2005).

The period between 2003 and 2005 evidenced the highest levels of violent deaths in Darfur. Attacks on villages were described in 2004 by the United Nations High Commissioner of Human Rights as constituting a "reign of terror" through the use of a "scorched earth policy" which had resulted in repeated war crimes and crimes against humanity being committed (U.N. News Centre, 2004). In 2005, the UN released the Report of the International Commission of Inquiry on Darfur to the United Nations Secretary-General which found that crimes against humanity had been committed by all actors: GOS, Janjaweed, and armed guerrillas of Darfur (International Commission of Inquiry on Darfur, 2005).

Rape was also systematically used as a weapon in Darfur, and was combined with racial insults to humiliate, demoralize, and disrupt tribal society (Amnesty Internatinal, 2004). If the underlying formula for a successful guerrilla insurgency is to be "among the people as fish are in water," Pruiner (2008) describes the government of Sudan's counterinsurgency policy as aiming to simply "drain the pond" (p.103). The complete destruction of villages and measures taken to discourage their reestablishment and targeting of peoples' livelihood conform accurately to this analogy. 
International Responses

\section{The $A U$ and the Ndjamena Peace Agreement}

Five months after being called "the world's greatest humanitarian disaster," the issue of Darfur was raised at the Security Council for the first time (Flint \& De Waal, 2005, p. 126). This was in July of 2004, nearly a year and a half after the first attacks went widespread in 2003. Resolution 1556 condemned the counter insurgency and called upon the government to recognize its own primary responsibility to protect, but contained incoherent and unenforceable recommendations for following up. It was careful not to encroach upon the sovereignty of the Sudanese government, who continued to remind the UN that Darfur was an internal matter, while adamantly refusing external interference (Badescu \& Bergholm, The Responsibility To Protect and the Conflict in Darfur: The Big Let-Down, 2009). One Amnesty International spokesperson described the resolution as "the abandonment of the people of Darfur and an abdication of the Security Council's role as a human rights enforcing agent" (Hoge, 2004).

With peace negotiations having begun in 2000 in Naivasha, Kenya towards a resolution in the drawn out civil war, oil beginning to flow a year earlier with China obtaining the largest supply contract, and the cooperation of the GoS on counter terror initiatives following September $11^{\text {th }}$, Sudan had found itself with unexpected leverage in the international community. Despite having the GoS at the bargaining table in Naivasha, "neither the SPLA/M under John Garang nor international observers and negotiators were willing to suspend talks to try to 
pressure the GOS to rein in the violence in the Darfur region" (Apsel, 2009, p. 243).

In 2003, as violence increased but enforcement mechanisms appeared unlikely, a number of diplomatic visits were dispatched to the region including the UN Secretary General, the High Commissioner for Human Rights, and the Special Advisor on the Prevention of Genocide. They all returned with the same conclusion: that the Government of Sudan must take immediate action to protect their citizens from crimes against humanity and war crimes. Despite these visits, all of 2003 and the beginning of 2004 were essentially lost, as all eyes stayed focused on Naivasha (United Nations High Commissioner for Human Rights, 2004).

On April $8^{\text {th }} 2004$, a ceasefire agreement was signed in Ndjamena, Chad, with the assistance of the AU leading the way for an observer force. The document has been described as fundamentally flawed, agreeing "to the neutralization of armed militia without defining what either the term 'militia' referred to or what 'neutralization' might mean" (De Waal, 2007). Either way, it was violated by all of the involved parties according to some sources within hours of being signed (Human Rights Watch, 2005). Shortly after the signing of the agreement, and with the UN's blessing through resolution 1564, the AU deployed an observer mission in Sudan (AMIS) to monitor and document, if not the ceasefire, then at least the evolving situation on the ground. 
The AU mission grew to 2,341 soldiers, 814 police officers, and 450 observers by the end of 2004 (Mamdani, 2009). The soldiers were initially tasked with protecting the observation team and documenting attacks and ceasefire violations, but lacked a protection mandate to intervene on behalf of villages or civilians in imminent danger. Flint \& De Waal (2005) described the mission as having been "thrown in the deep end...[with] fewer staff working on Sudan than the Darfur unit of a medium-sized international NGO" (p.120). In 2005, the AU's mandate was expanded to include the protection of civilians when possible and when they were experiencing an imminent threat.

Despite being underfunded and understaffed, the AU deployment did eventually coincide with a reduction in deaths starting around the beginning of 2005, and laid the groundwork for a second peace agreement. According to Mamdani (2009), the AU was "able to radically reduce deaths from political violence" (p. 38), while an increased NGO presence in Darfur worked to provide water in the prevailing drought conditions, further reducing overall death tolls. A report issued by Refugees International found that the $\mathrm{AU}$ had been able to bring “a modicum of additional security in certain locations," including in IDP camps, but had been ultimately restricted in its ability by a lack of funding and logistical support (Refugees International, 2005). Another report issued by the Feinstein center also found that security had improved in the Kebkabiya province in northern Darfur, where the AU had established a presence (Feinstein International Famine Center, 2005). Finally, De Waal (2007) writes, "in the 
twelve months after its initial deployment in July-August 2004, AMIS helped bring increased stability to most areas of Darfur" (p.377).

Even if the AU had had the bureaucratic capacity to absorb further support from the developed world for its observer mission, it did not receive it. Even from its own member states, AMIS ran into difficulty amassing funds for its first peacekeeping mission, as around $75 \%$ of the AU budget is contributed by only five countries consisting of South Africa, Egypt, Libya, Nigeria, and Algeria (Badescu \& Bergholm, The Responsibility To Protect and the Conflict in Darfur: The Big Let-Down, 2009). AMIS was further restricted in their movement by a 6pm - 6am curfew imposed by the government, was often subject to "temporary fuel shortages" and had no aerial defensive capabilities (Steidle, 2007). With a 200 million dollar deficit in July of 2005, and faced with difficulties collecting upon pledged support, soldiers would regularly go many months without being paid, and many had been forced to take loans (Williams, 2006).

Given the amount that AMIS achieved in the areas that it established a presence, on the budget it was given, one can deduce that adequate support of the AU mission would have increased its effectiveness. As the push for a UN takeover grew, the already insufficient support for the AU mission continued to decline until in January of 2006, recognizing its own limitations, the AU itself began calling for a UN takeover for its role in Darfur. 
Darfur Peace Agreement

The Darfur Peace Agreement (DPA), signed on the $5^{\text {th }}$ of May, 2006 in Abuja, Nigeria was a significant improvement upon the N'Djamena document. Despite these improvements, is has been widely criticized for being unenforceable, insufficient, and entirely contingent upon the cooperation of Khartoum (Wadlow, 2006). The DPA was also signed under immense pressure by the international community, particularly the United States, who "strong armed" it to completion (Fadul \& Tanner, 2007).

Lacking the economic strength to survive independently, the DPA did not entertain the hope of independence for Darfur, unlike with the CPA in the south. The DPA also severely underfunded compensation for war affected victims and their families, (what amounted to around $\$ 10$ per person) and relied on the government to abide by peace agreements for the very violence they were responsible for starting (Prunier, 2008, p. 164). As Reeves (2007) argues, the biggest problem with the agreement was its "failure to provide meaningful international guarantors for the exceedingly complex security arrangementsarrangements that Khartoum has consistently and comprehensively flouted from the moment the document was signed" (p.10). It was, on paper and in practice, the second non-starter in the Darfur peace process.

International pressure to produce something tangible through the imposition of external deadlines, and inflexibility on behalf of the negotiating parties, led to a failure in consensus building, and was a detriment to the process 
and the outcome of the agreement (Nathan, 2007). Stall tactics by the GoS slowed the mediation process, while its suggestions, such as placing the AU in charge of disarming the rebels, while it would take responsibility for disarming the Janjaweed, lead one to question the seriousness with which it approached the negotiations (Prunier, 2008).

The utter lack of mutual trust between parties during the negotiations, along with the external pressure to produce a tangible document as soon as possible, led to the signing of the agreement by only one of the leaders within the SLM/A, Minni Minnawi. Others within the SLM who were dissatisfied with the agreement immediately split from the Minnawi faction, vowing not to honor the DPA ceasefire. The splintering continued under a variety of underlying motivations, resulting eventually in around 15 separate guerrilla movements fighting in Darfur (Prunier, 2008). The JEM also refused to sign the agreement. With the underlying rift in the SLM/A blown apart by the DPA, open warfare emerged between the groups for superiority, while "rouge" factions shed much of their political motivation and frequently resorted to attacking and looting villages in their vicinity (Mamdani, 2009). As Natsios (2007) pointed out during his testimony to the Senate foreign relations committee, "Rebel leaders frequently appear more focused on their own ambitions than on the wellbeing of the people of Darfur."

In August of 2006, the Security Council again tried their hands at a resolution, number 1706, which "invited the consent" of Sudan for a UN takeover 
of the AU mission (U.N. Security Council, 2006). Citing the inviolability of his state's sovereignty, Al-Bashir politely declined. The International Crisis Group reported, in November of 2007, that since the beginning of the year, there had been over 240,000 newly displaced or re-displaced persons, and that attacks against Darfurians had risen 150 per cent over the previous year (International Crisis Group, 2007). In September 2007, splinter groups from the SLA attacked an AU base killing at least 10 peacekeepers and wounding many more (Polgreen, 2007). With attackers following no clear allegiances, and the 2005 cessation of violence now reversing against the efforts of an under-funded AU team, the situation following the DPA had become worse than before.

\section{UNAMID}

Four years after the outbreak of violence in Darfur, the approval of UN Security Council resolution 1769 in July of 2007, with all 15 members in favor, cleared the way for UN peacekeepers. The mission would be merged together with the AU AMIS troops in a first of its kind "hybrid force," and was aimed at implementing the Darfur Peace Agreement and upholding the ceasefire (U.N. Security Council, 2007). It got off to a slow start. Prunier (2008) has described its activation in December of 2007 as a ceremonious "re-hatting" from green helmets to blue, yet remaining "as unmotivated, as inefficient and as underequipped as they had been under their previous name" (p. 178).

Despite paragraph 15 (2) of the resolution clearly stating that, acting under Chapter VII, UNAMID shall "protect civilians, without prejudice to the 
responsibility of the Government of Sudan" (U.N. Security Council, 2007). The GoS has done its best to make this task as difficult as possible for the UN, with an official from the defense ministry even claiming that they only had the right to defend themselves (Abass, 2007). UNAMID also suffers from similar limitations in its operational capacity as AMIS did, including requiring permission for night flights, mounting rescue or reinforcement missions for their own troops who come under fire, and being relegated only to an "observe and encourage" position in the disarming of the Janjaweed (Badescu \& Bergholm, The Responsibility To Protect and the Conflict in Darfur: The Big Let-Down, 2009; Report of the Secretary-General and the Chairperson of the African Union Commission, 2007). Attacks on UNAMID have been frequent and 57 UN personnel have been killed so far (UNAMID Facts and Figures, 2010).

As of 2009, the deployment reached its full capacity, consisting of 21,800 total uniformed personnel, including 16,852 troops, 273 military observers, and 4,675 police officers (UNAMID Facts and Figures, 2010). While Darfur has seen dramatic improvements since the full deployment of UNAMID, the situation remains extremely volatile. In its Aug 9, 2009 extension of the hybrid mission two years after its inception, the UN expressed concern over the "continued seriousness of the security situation and deterioration of the humanitarian situation in Darfur, and at the recurring attacks on the civilian population" (U.N. Security Council, 2009). On 25 February of 2010, a day after Omar al-Bashir proclaimed that the war in Darfur was over, Reuters reported that the NGO 
Medicines du Monde was forced to halt their operations in Jabel Marra due to fighting between rebel and government forces, while an estimated 100,000 were forced to flee from the region (Reuters, 2010).

\section{ICC Indictment}

In 2009, the ICC issued an arrest warrant for the president of Sudan. In the warrant it wrote that it "was satisfied that there are reasonable grounds to believe that Omar Al-Bashir is criminally responsible under article 25(3)(a) of the Statute as an indirect perpetrator, or as an indirect co-perpetrator, for war crimes and crimes against humanity and that his arrest appears to be necessary under article 58(l)(b) of the Rome Statute" (International Criminal Court, 2009).

The action is open to the criticism that, as it's essentially unenforceable, only serves to complicate the process of reconciliation in Darfur, and meanwhile has provoked the GoS which kicked out a number of humanitarian aid groups. By setting such precedence however, the warrant has also established that even acting heads of state will not be immune from persecution against such crimes. As a result, Al-Bashir has been severely de-legitimized and will likely suffer politically, as Slobodan Milošević did after being indicted by the International Criminal Tribunal. Whether or not this will ultimately serve to moderate the GoS or contribute to the de-escalation of conflict however, remains to be seen.

\section{Death Toll}

Establishing the number of casualties starting from the rebel attacks in February of 2003 through the brutal government counterinsurgency has been an 
extremely contested, and at times political exercise. The U.S. Department of State estimated, between March 2004 and January 2005, a total of between 98,000 and 181,000 deaths, while other reports between February and August of the same years have reached as high as 400,000 (U.S. Government Accountablity Office, 2006). The difficulty in establishing accurate findings is due in part to the obstacles in collecting the data on the ground, as well as differing opinions on the extent to which the tactics of privation, as a counterinsurgency tool, should be included in the estimates. Daly poses the dilemma in counting the dead when he writes, "are malnourished children dying from dysentery in squalid camps surrounded by Janjaweed to be counted as victims...?" (Daly, 2007).

A study conducted by Centre for Research on the Epidemiology of Disasters, working primarily from statistical analysis of around 30 mortality surveys and receiving the highest level of confidence from the United States Government Accountability Office, which stepped in to mediate the numbers debate, reported 170,237 deaths over a 22 month period between 2003 and 2005 (U.S. Government Accountablity Office, 2006). 180,000 later became the official UN figure in March of 2005 (New York Times, 2005). A more recent study financed by the European Commission and the U.S. Department of State extended the time frame to the end of 2008 and concluded with 298,271 deaths (Degomme \& Guha-Sapir, 2010). Even though, as Tubiana (2007) notes, "there are no reliable figures" (p.68), the lowest of the death toll ranges, widely acknowledged to be in the hundreds of thousands, are clearly far too high. 
The totals of war-affected persons in Darfur have, for some time, been in the millions, while the number of internally displaced persons, as reported by the Office for the Coordination of Humanitarian Affairs in January of 2009 reached 2,667,682; more than double its April 2004 figures of around 1 million (United Nations Office for the Coordination of Humanitarian Affairs, 2009). Genocide

The declaration of the United States Congress and President Bush that the situation in Darfur as a genocide was followed by a similar, but much less committed, finding by the EU that the events in Darfur were "tantamount to genocide" (Bock \& Miller, 2004). These declarations presented an opportunity to observe the mechanics of the invocation of the Genocide convention and its requirements for action.

Contrary to the American declaration and the European quasi-declaration, in 2005, the UN commission of inquiry conducted by the Office of the High Commissioner for Human Rights, found that the "Government of Sudan has not pursued a policy of genocide" (BBC, 2010). It cited that forced displacement was more common than the killing of entire villages and suggested that the violence more resembled a terribly brutal counter-insurgency with potentially "individual" acts of genocide, rather than a mechanized government attempt to eliminate, in whole or part, one particular group (International Commission of Inquiry on Darfur, 2005). The attacks committed by the splintered former-SLA 
soldiers, following the signing of the DPA, added to the non-genocidal elements in characterizing the overall nature of violence.

Contention over the genocide question was illustrated through the testimony of the U.S. Special Envoy to Sudan, Andrew Natsios to the Senate Foreign Relations Committee. Towards the beginning of his report in April, he described the events in 2003 to 2004 as having "led to genocide," but was exceedingly cautious during his testimony to describe the present situation in Darfur as genocide, illustrating instead the complexity of the situation (United States Senate, 2007). Mamdani (2009) quotes the follow-up questioning after Natsios's testimony, where he takes great pains in illustrating the evolving nature of the violence in Darfur, which by 2007, included intra-tribe rape, rebel atrocities and attacks, loss of Government control, and the shifting of some of the worst violence into neighboring Chad. All of these factors contradicted a simple categorical designation of genocide.

Contrastingly, interviews of eyewitnesses to attacks in 2003 and 2004 have recorded widespread use of racial insults directly accompanying fatal violence (Hagan \& Rymond-Richmond, 2009). Once the UN referred the issue to the ICC, the chief prosecutor, Luis Moreno Ocampo pushed for the inclusion of genocide in the indictment of president Al-Bashir in 2009, but the court decided not to include it in the final arrest warrant that was issued (Hagan \& RymondRichmond, 2009). Prunier (2008) illustrates the complexity of violence in Darfur when he writes "[t]he practice of genocide or quasi-genocide in Sudan has never 
been a deliberate well-though out policy, but rather a spontaneous tool used for keeping together a 'country' which is under minority Arab domination" (p.105). Darfur thus cannot serve as a case study for the invocation of an international response as required by an enactment of the genocide convention.

While the use of the term, "genocide," remains a disputed issue, the severity and nature of violence meeting the conditions for crimes against humanity and war crimes is not. The UN Commission of Inquiry found widespread evidence of both crimes against humanity and war crimes, and also recognized the role that ethnicity played in the violence and forced displacement by describing it as "ethnic cleansing" (International Commission of Inquiry on Darfur, 2005).

The Government of Sudan played a central role in the arming and inciting of militant groups to purposefully target civilians within three dominant tribal groups as a counter-insurgency tactic. It also masterfully enacted diplomatic subterfuge to delay or prevent the spread of information and the progress of conflict resolution. Still, the problem of co-opting the language of genocide, as a tool for fast-track military action, illustrates the importance of both earlywarning and thorough information gathering on the ground in areas of conflict, for the enactment of existing treaties and best practices by the international community.

The norm of non-intervention was upheld in the Darfur crisis, while legal provisions for the protection of innocent civilians such as the Genocide 
convention were not applied. Despite cries in the west for protection in Darfur, nearly reaching the level of populist rage around 2005, little changed in the international response. The conflict of non-intervention and protection was at the center of the response to Darfur.

As previously mentioned, an international conflict response framework for situations involving both an immediate need for protection, and a belligerent, recalcitrant government will be difficult to achieve. Nevertheless, the simple act of identifying needs on both sides of the debate and subjecting them to careful reflection will inform and direct the first tentative steps. These steps must be cautious in respecting international law and state sovereignty, while also taking conclusive measures to protect victims of genocide, crimes against humanity, war crimes, and ethnic cleansing. The following report credits itself as attempting to develop such a balance. 
The Responsibility to Protect

\section{Formation and Content}

One attempt at reconciling the non-intervention/protection debate has made surprising gains in a relatively short amount of time. It is the subject of this section.

During a speech in 2000, Kofi Annan sought to improve responses to humanitarian catastrophe by illustrating the importance of finding a way to navigate the conflict between sovereign inviolability and the protection of individuals. He asked, "...if humanitarian intervention is, indeed, an unacceptable assault on sovereignty, how should we respond to a Rwanda, to a Srebrenica - to gross and systematic violations of human rights that affect every precept of our common humanity?" (Report of the Secretary-General on the work of the Organization, 2000).

In October of 2001, the International Commission on Intervention and State Sovereignty (ICISS) was formed with sponsorship from the Canadian government to find an answer to Annan's question. Co-chaired by Gareth Evans of Australia, and Mohamed Sahnoun of Algeria, the ICISS was composed of 12 diplomats, foreign ministers, and a former president, from an even representation of countries consisting of both northern and southern economic and security interests. Its task was to build a set of principles and guidelines for addressing humanitarian disasters, particularly those involving large-scale loss of 
life as a result of government involvement, complacency, or inability to halt such violence.

The formation of the commission followed the tragic failures to prevent or halt mass killings, repeatedly witnessed during the 1990's, including in Rwanda, Srebrenica, and East Timor (Thakur, Crisis and Response, 2008). The commission recognized that the tension between non-intervention and protection was at the crux of the failures of initiating timely and effective conflict resolution measures for saving lives during the outbreak of humanitarian disasters. As the ICISS recognized; [i]n the interest of all those victims who suffer and die when leadership and institutions fail, it is crucial that these differences be resolved" (ICISS, 2001, p. 2).

These differences, partially brought on by the so-called "right to humanitarian intervention" had stifled progress on the subject of force, as it relates to protection and sovereignty. Among the main goals of the ICISS was to restart and reframe the debate by looking at the positions of entrenched parties through the perspective of interests. The ICISS drafted its report, "The Responsibility to Protect" (commonly referred to as R2P), which attempts to both improve the legal (UN sanctioned) framework for the prevention and response to mass scale humanitarian disasters, as well as seek out common ground towards developing consensus.

In essence, the report is a list of recommendations for UN reform, particularly within the Security Council, addressing past failures to respond and 
prevent. The R2P also references and endorses a number of different UN special reports over the past 20 years, consolidating and combining them with its own recommendations. Lending further creditability to the R2P, many of its findings were also echoed by the 2004 UN High-level Panel on Threats, Challenges and Change, particularly in the areas of UN reform, prevention, peace building, and timely response (High-Level Panel on Threats, Challenges and Change, 2004). The ability of ICISS committee, despite its diverse composition, to reach a general consensus in their recommendations on such a potentially explosive issue provided a glimmer of hope that a similar agreement might be possible within the international community (Weiss, 2007).

This hope appeared briefly justified in 2005 when the UN World Summit produced an outcome document agreeing upon the principles of the R2P. Resulting from a unanimous vote in one of the largest gatherings of world leaders in history, it has perhaps been the largest step to date in recognizing the existence of an emerging protection norm. The outcome document established and clarified the four crimes to be considered applicable for the responsibility to protect as genocide, war crimes, ethnic cleansing, and crimes against humanity. These will be subsequently referred to as "R2P type crimes."

The outcome document reads; "Each individual State has the responsibility to protect its populations from genocide, war crimes, ethnic cleansing and crimes against humanity. This responsibility entails the prevention of such crimes, including their incitement, through appropriate and necessary 
means" (U.N. General Assembly Res/60/1, 2005). This clearly implies that sovereignty has acquired the feature of responsibility, and shed the feature of impunity. The heads of state then went on to agree that, "we accept that responsibility and will act in accordance with it" (para 138).

The next paragraph recognizes that:

The international community, through the United Nations, also has the responsibility to use appropriate diplomatic, humanitarian, and other peaceful means, in accordance with Chapters VI and VIII of the Charter, to help to protect populations from genocide, war crimes, ethnic cleansing and crimes against humanity. In this context, we are prepared to take collective action, in a timely and decisive manner, through the Security Council, in accordance with the Charter, including Chapter VII, on a caseby-case basis and in cooperation with relevant regional organizations as appropriate, should peaceful means be inadequate and national authorities are manifestly failing to protect their populations from genocide, war crimes, ethnic cleansing and crimes against humanity (U.N. General Assembly, 60 ${ }^{\text {th }}$ Sess., 2005 para.139)

Thus, the outcome document does not endorse the exercise of military intervention outside of the Security Council, but does call upon the international community to help states exercise their responsibility to protect within the laws of the UN charter.

The recognition of the R2P by the World Summit has since been echoed by 
UN organizations and NGOs, including Human Rights Watch, International Crisis Group, Oxfam International, Refugees International, the High Commissioner of Human Rights, and the High Commissioner for Refugees. Its terminology has also been used in the General Assembly and the Security Council. Most of the recommendations of the ICISS were also echoed in 2004 by the UN Panel on Threats Challenges and Change, which found that if the Security Council were to adopt a new set of guidelines closely resembling the ones established by the R2P orchestrating the use of force in situations of genocide, ethnic cleansing, and other large scale killing, that it would contribute to achieving consensus on the use of coercive action, including armed force (U.N. General Assembly Res/59/565, 2004). Such a consensus would serve to clarify the rules surrounding the use of force when the Security Council decides it necessary, and minimize the chances of illegal unilateral or multilateral action.

To better understand the content of the R2P, we will look at the three stages of responsibility with which the ICISS structured their recommendations. These include the prevention of conflict, timely and authorized response to conflict through protection, and the rebuilding phase following conflict.

\section{Prevention}

The first tier of responsibility, and the "single most important dimension of the responsibility to protect" is that of prevention (ICISS, 2001, p. xi). The responsibility to prevent consists of recommendations spanning a range from less coercive measures that can be taken outside the UN by individual states, 
NGOs, and development organizations to more coercive ones that would require Security Council approval.

Prevention measures addressing "root cause" issues include strengthening development and poverty reduction programs, political and legal capacity building, as well as minority and human rights programs. NGOs are positioned uniquely here, as they can often establish a direct working relationship with those they are helping, while UN organizations such as the Office for the High Commissioner for Human Rights can dispatch fact-finding missions, and receive and examine complaint petitions against states that are party to relevant human rights treaties.

More coercive preventative measures include "the threat or application of political sanctions, diplomatic isolation, suspension of organizations membership, travel and asset restrictions on targeted persons, 'naming and shaming', and other such actions"' (ICISS, 2001, p. 24). These measures would include the use of "smart sanctions" which target specific groups or individuals within the government, rather than imposing general blockades, and which demonstrated moderate successes in Iraq, Libya, Cambodia and Angola (Cortright \& Lopez, 2002).

Prevention is tied together and relies upon the improvement of early warning systems. The ICISS recognizes that the ability to both gather and process information on imminent or recently emerged conflict, and distributing such information to where it can be best applied, will precede effective conflict 
prevention. To this end, the commission recommended establishing an exclusive office under supervision of the Secretary-General with the ability to "receive and analyze sensitive information from member states and others" which would be staffed by persons specialized in conflict prevention (ICISS, 2001, p. 22). Early warning was also among the specific recommendations made in the 2005 outcome document, where world leaders called upon the international community to assist the UN in establishing a central early warning capacity.

The ICISS also highlighted and fully endorsed the findings of the UN Report on the Prevention of Armed Conflict. The report recommended, inter alia, that the General Assembly make greater use of its powers for conflict prevention, and that the Security Council take a greater role in preventative, rather than reactive measures. One specific recommendation by the report was to build a permanent committee "to discuss prevention cases on a continuing basis...[based on] cases brought to its attention by Members States" (U.N. General Assembly Res/55/281, 2001).

Preventative military deployments are also briefly mentioned as an element of the responsibility to prevent through the example of the UN Preventive Deployment Force in the Republic of Macedonia with the government's approval (UNPREDEP). The mission which, at its height employed 1,050 troops, has widely been considered successful in preventing a spillover of violence from the region into Macedonia by monitoring smuggling activities and performing close to 400 patrols a week in order to prevent arms flow and 
provide security(United Nations Department of Public Information, 1999).

The peacekeeping mission was ended by a Chinese veto following the official recognition of Taiwan by the Republic of Macedonia.

Even with sufficiently funded and supported prevention programs that are fully "exhausted before intervention is contemplated" (ICISS, 2001 p.xi), contingencies must be prepared for. Societies developed under normative structures of opportunity and equality are still susceptible to unforeseen sources of violence and instability, and even the best prevention cannot be expected to eliminate all emerging situations of violence.

Protection, Just Cause \& Right Authority

When prevention measures fail to avert cases of R2P type crimes, the ICISS issued recommendations for the protection of individuals that build upon the concept of sovereignty as responsibility established by Cohen \& Deng. The R2P states that " $[\mathrm{w}]$ here a population is suffering serious harm, as a result of internal war, insurgency, repression, or state failure, and the state in question is unwilling or unable to halt or avert it, the principle of non-intervention yields to the international responsibility to protect" (ICISS, 2001, p. xi)

Protection does not automatically translate into military force, and there are potentially many ways of fulfilling the responsibility to protect. Many of these follow the continuum of measures started in the prevention stage. Strengthening or widening smart sanctions, imposing and enforcing no-fly zones, or administering travel restrictions, are all recognized by the ICISS as possible early 
measures in the protection stage, that could have also been started in the stages of prevention.

The ICISS recognized that the norm of non-intervention must be the very foundation, from which all further actions are justified. The norm of nonintervention and the role of sovereignty act as the protectorate of "not only...states and governments...[but also]...peoples and cultures, enabling societies to maintain the religious, ethnic, and civilization differences that they cherish" (ICISS, 2001, p. 31).

In accordance with the UN Charter however, the ICISS recognizes that the norm of non-intervention is not unlimited. There exist certain criteria, particularly where threats to the peace are concerned, or in situations where the norm of non-intervention must be reconsidered for threats to the international peace and security. The question then becomes, what constitutes an emergency, and who decides when the criteria are reached? The former is the question of just cause, and the later of right authority.

In determining just cause the ICISS proposed the criteria of: Large scale loss of life, actual or apprehended, with genocidal intent or not, which is the product either of deliberate state action, or state neglect or inability to act, or a failed state situation; or ...large scale 'ethnic cleansing', actual or apprehended, whether carried out by killing, forced expulsion, acts of terror or rape (ICISS, 2001, p. xii).

It was this just cause wording that was condensed down to the four above- 
mentioned R2P type crimes in the 2005 World Summit. In determining the question of right authority, the Commission placed no body, or source of authority, above that of the Security Council.

By limiting the focus of the responsibility to protect, the ICISS focuses its efforts on the types of international conflict where the worst atrocities occur and large-scale loss of life is involved. Thus, international occurrences which do not amount to jus cogens violations, and which would be excluded from invoking an international responsibility to react, are many. Some examples include widespread discrimination (assuming it does not amount to apartheid), restriction of individual liberties such as freedom of expression or movement, the overthrow of democratically elected governments, natural disasters, and the harboring of terrorists.

Such examples could certainly be subject to prevention initiatives under the auspices of the UN or international organizations, and they could also potentially lead to R2P type crimes, but they are not, per se, addressed by the responsibility to protect. Setting the just cause threshold high was a deliberate attempt by the ICISS to focus consensus-building efforts on the most dire of circumstances. The R2P was both designed to make as much impact as possible in a narrow field, as well as to avoid being used as a justification tool for the imposition of national interests. Consequently, the ICISS does not advocate alternate interpretations of the Charter that argue humanitarian intervention is allowed outside UN authorization. 
Because the ICISS places nothing before the UN Security Council in authorizing military action against R2P type crimes, the majority of its recommendations are directed towards the world body. Most recommendations are aimed at managing the usage of the veto power vested in the permanent five members (P5) of the Security Council. The first recommendation is that the P5 agree to adhere to a "code of conduct" which limits the usage of a state's veto power in R2P type crimes. According to the code of conduct, a State would not, “...where its vital national interests were not claimed to be involved...use its veto to obstruct the passage of what would otherwise be a majority resolution" (ICISS, 2001, p. 51).

The skeleton in the closet here clearly is the meaning of "vital national interest," not to mention that the impetus for using the veto rarely comes from anything perceived to be less. This is however, barring a discussion on UN reform and the nature of the current Security Council makeup, an obvious limitation of the body to act as impartial on behalf of humanity. Realists might argue that to conceive of such a body is impossible, others that this is the very point of the veto. If we focus through the lens of saving lives however, the very act of forging a formal agreement, such an agreement would arguably be a significant first step in improving P5 cooperation for R2P type crimes, without entering into the debate over retooling the present power balance. 
In the case that the "code of conduct" provision does not prevent Security Council paralysis, the ICISS recommended two other methods for fulfilling the international responsibility to protect.

The first alternative is known as "uniting for peace" and takes place within the General Assembly. The procedure was created by resolution 377 in 1950 as a contingency for overcoming Security Council deadlock while meeting the Charter obligation of maintaining international peace and security. In the resolution, the General Assembly:

Resolves that if the Security Council, because of lack of unanimity of the permanent members, fails to exercise its primary responsibility for the maintenance of international peace and security in any case where there appears to be a threat to the peace, breach of the peace, or act of aggression, the General Assembly shall consider the matter immediately with a view to making appropriate recommendations to Members for collective measures, including in the case of a breach of the peace or act of aggression, the use of armed force when necessary, to maintain or restore international peace and security. If not in session at the time, the General Assembly may meet in emergency special session within twenty-four hours of the request there for. Such emergency special session shall be called if requested by the Security Council on the vote of any seven members, or by a majority of the Members of the United Nations (U.N. General Assembly Res/5/377, 1950). 
It was during such a "uniting for peace" session that one of the first peacekeeping missions, UNEF, was established in 1956 as a response to the Suez Crisis, achieving a moderate de-escalation of tensions along the Israeli-Egyptian border(Thakur, 2006). The "uniting for peace" option has not yet been invoked in practice for conflicts meeting the conditions of R2P type crimes.

The second recommendation by the ICISS in the case of Security Council deadlock is for a larger role to be played by regional organizations such as the $\mathrm{AU}$, ASEAN, or NATO, in bringing an end to R2P type crimes. In meeting the responsibility to protect through the use of military force, these regional organizations would require the approval of the Security Council for their operations, as was the case with the AU in Darfur. This suggestion has precedence under chapter VIII of the UN Charter, which allows for "regional arrangements or agencies for dealing with such matters relating to the maintenance of international peace and security..." (Charter of the United Nations, 2006), provided that the Security Council allows it.

Resolutions authorizing regional organizations to address crises within their own member states, rather than the UN itself, may be less politically divisive for reaching Security Council agreement, and more likely to obtain consent by the state in question. The $\mathrm{AU}$, for example, was able to get a toe in the door with the government of Sudan through the philosophy of "African solutions for African problems." Of course, as mentioned earlier, the mission was still well below the response necessary for halting the violence and stopping the GoS, which was 
perhaps one of the reasons they ultimately consented to it. With the continued improvement of regional organizations this is likely to improve. The NATO involvement in Bosnia in the early 90's, which was approved and sanctioned by the UN, is another example of the involvement of regional organizations, however its 1999 Kosovo campaign, having been waged without Security Council approval, would not be. Finally, the ICISS also floated the suggestion that action taken to fulfill the responsibility to protect by regional organizations might still be found legitimate, even if authorization were sought ex post facto.

While addressing the question of unauthorized military intervention, the ICISS was content to point out the dangers of a world where humanitarian intervention is conducted outside UN authorization for the wrong reasons, and the dangers for the UN, if it is successfully done for the right ones. It's worth restating this for the sake of clarity; neither the R2P report, nor the 2005 outcome document, have authorized or argued for military force outside UN authority. In fact, the Responsibility to Protect gives the impression of being genuinely concerned over the fate of international peace and security, should the UN happen to veto itself into irrelevancy. In a word, the ICISS answer to Annan's earlier question seems to be, "fix your organization."

\section{Rebuilding}

Finally, should the exercise of peacekeeping or intervention be necessary, the R2P establishes a "responsibility to rebuild" inspired by the principles of 
structural peace building. The commission viewed rebuilding as belonging to the process of reconciliation and central in preventing the re-emergence of conflict. Peace building follows the patterns recommended by Secretary General Boutros Boutros-Ghali as actions "to identify and support structures which will tend to strengthen and solidify peace in order to avoid a relapse into conflict" (Report of the Secretary General, 1992, p. 11). Conforming to peace psychologist Johan Galtung's description of peace building as an "associative" approach, the R2P combines many elements for the development of peaceful societies (Langholtz, 1998, p. 10). Included in the rebuilding process is the assurance of security, development of a functional court system, and the encouragement of local ownership through "creating patterns of cooperation between antagonistic groups" (ICISS, 2001, p. 45).

As the ICISS points out, "true reconciliation is best generated by ground level reconstruction efforts, when former armed adversaries join hands in rebuilding their community or creating reasonable living and job conditions at new settlements" (ICISS, 2001, p. 47).

Like elsewhere, the R2P draws from previous UN findings and endorses the 1998 report on The causes of Conflict and the Promotion of Durable Peace and Sustainable Development in Africa. In it, the report highlights the importance of coordinating the efforts of promoting local economic growth, infrastructure development, strengthening democratic governance, and maintaining security through the example of the United Nations Peace-Building Support Office in 
Liberia which served to coordinate and improve the responses of the many different actors involved in the post conflict peace building process (Report of the Secretary-General, 1998, p. 69).

\section{R2P and the tension}

The R2P navigates the tension between norm of non-intervention and protection with varying degrees of success. While the threat posed to sovereignty by the responsibility to protect appears minimal, other concerns such as empire on the one hand, and insufficiency of response on the other, make the R2P no more than a starting point for the consensus building that must precede a new response framework for humanitarian crises. In many ways, the R2P works towards a win/win outcome for the conflict. By issuing recommendations that build on already established UN reports, recognizing the concerns on both sides of the debate, and supporting the prohibition on the use of force without Security Council authorization, the ICISS has drawn its report carefully down the middle.

While this is a strength, it is also a weakness, and opens the R2P up to the criticism that it takes not enough concrete steps in either direction. Bullish humanitarians will argue that it does not go far enough in endorsing the use of force, while strict non-interventionists will claim that its recommendations aim to weaken the current restrictions already in place.

The narrow applicability of the intervention clauses in the R2P, as well as the fact that the recommendations made by the ICISS do not violate the UN Charter, serve to lend credibility to the document. Its impact on international law, 
as it relates force, does not immediately change or alter the present landscape. If, through its recommendations, it is able to alter the reaction behavior in the UN towards emerging R2P type crimes, it certainly has the potential for inciting the development of a new norm, and might safely be called "emerging."

Prevention in the R2P has the potential for meeting concerns on both sides of the non-intervention/protection debate. As recommended by the ICISS, it can be performed in accordance with international law, and by respecting the inviolability of state sovereignty. At present, the recommendations for improved prevention measures, as made by the ICISS, remain unrealized and lacking in momentum, while the 2005 world summit largely overlooked prevention, other than mentioning the need for improved early warning (Bellamy, Conflict Prevention and the Responsibility to Protect, 2008).

With protection, the concept of "sovereignty as responsibility" does not appear to fundamentally alter, threaten, or undermine the current nature of state sovereignty, much less the role that it plays as the foundation for international relations. Sovereignty has long made accommodations for changing views and practice in minority rights, human rights, globalization and even international lending. As Krasner rightly points out, the flexibility that sovereignty has shown throughout its history illustrates that it lacks features of "embeddedness or taken-for-grantedness," exhibiting features more aptly resembling an "organized hypocrisy" instead (Krasner, 1999). Also, it is repeatedly highlighted in the ICISS 
and the outcome document that the primary responsibility remains with the state itself. Sovereignty as responsibility is a rhetorical tool for reminding states of their standing obligations under existing law.

UN member states have always been subject to the rulings of the Security Council should they be found in breach of the peace, and although rare, even when such rulings may violate a state's Westphalian sovereignty. As the ICISS made clear, in becoming a signatory to the UN Charter, sovereignty undergoes no "transfer or dilution...but there is a necessary re-characterization involved: from sovereignty as control to sovereignty as responsibility both in internal functions and external duties" (ICISS, 2001, p. 13). Thus, in the R2P, sovereignty as responsibility reiterates the conditions of becoming a member of the UN that have existed since its inception.

A persistent misconception that the R2P would erode legal state sovereignty, and make unauthorized military intervention easier, has led to a pushback worth exploring in more detail. In 2008, following the recognition of the R2P in the World Summit, again in the General Assembly, and later in the Security Council, the UN began the process of implementing a special advisor for the responsibility to protect. During a budget committee meeting, delegates from the Middle East, Africa, and Latin America decided that "the World Summit rejected R2P in 2005 ', 'the concept of the responsibility to protect has not been adopted by the General Assembly', and that 'the responsibility to protect itself ... 
was not accepted or approved as a principle by the General Assembly'" (Evans, 2008).

This resistance was encountered during the appointment of Edward Luck as a special advisor on the responsibility to protect by the Secretary General. Ultimately, Mr. Luck was appointed, but in order to avoid being blocked in the budgetary approval process, would be paid one dollar per year under a temporary status, and was left with a vague mandate other than to explore how to "further" the ideas contained in the outcome document (U.N. General Assembly 62nd Sess., 2008).

General misunderstanding over the scope and implications of the R2P may be partially at fault. One argument is that the $\mathrm{R} 2 \mathrm{P}$ was derived from humanitarian intervention, and was "intended to enlarge the basis of support for it" (Newman, 2009, p. 98). Unfortunately, this interpretation of the R2P seems to brush aside the deliberately cautious approach it takes, as well as the legal restrictions it accepts. If the R2P does derive from humanitarian intervention, it does so only from the fallout left by the zero-sum approach of those arguing for the right to humanitarian intervention. As the R2P clearly indicates, the ICISS did not intend to expand support for the illegal use of force, but rather to stimulate and reframe the deadlocked debate. By calling attention to the insufficiency of the response framework for R2P type crimes, and placing it squarely on the international agenda, it has already done much. 
In the direct aftermath of the R2P's rise to popularity, there were a number of conflicts that attempted to claim its vocabulary for themselves. These included the American invasion of Iraq, the conflict in South Osetia, and the French attempt to invoke the R2P to open-up the restrictive government of Burma to provide humanitarian aid following cyclone Nargis. None of these were successful in convincing the international community that the R2P was interested only in serving the interests of the powerful.

Some states have even sought to clarify these misconceptions. As Chile pointed out during the Plenary Meeting of the General Assembly on the R2P, "misuse of a concept does not invalidate it" (Badescu \& Weiss, 2010). Even the case of Iraq, as Thakur (2005) has argued, demonstrates the importance of the $\mathrm{R} 2 \mathrm{P}$ as a tool to bring legal clarification and consensus in the nonintervention/protection conflict. Indeed this may already be happening, as each case where the R2P was appropriated, the resulting discussion seems to have served to establish clearer boundaries on what the emerging norm is not, rather than convince anybody that it is a Trojan horse for empire-building (Badescu \& Weiss, 2010).

This interpretation has also been confirmed by the 2009 report of the Secretary General on implementing the responsibility to protect. In it, Ban KiMoon made a plea for unity around the summit outcome document, while also attempting to clarify common misconceptions. He argues that quick action towards saving lives must trump bureaucratic policy, and advocates the 
development of a rapid response agency consisting of both civilian and police actors, which can be deployed in situations of rapidly escalating R2P type crimes (U.N. General Assembly Res/63/677, 2009).

Conflict prevention or rebuilding, that include the opening and developing of economies to a global-rather than local-market, is a weakness of the R2P. The construction of industry, economic opportunity, and functioning social services are necessary for the development of peaceful societies. However, the dangers of imperial influence, whether through NGOs, economic organizations, or corporate exploit are significant. Particularly as cheap labor increasingly fuels the global economy, and satisfies its raison d'être of increasing demand and expanding the market, identifying and working against imperial dispersion will be crucial.

Of course, the question of whether prevention, protection, and rebuilding activities do result in the spread of empire will depend on our working definition of the concept. If empire is centralized in a hegemonic power, certain diplomatic and legal measures that can be taken to shun, or clearly label such behavior. Instead, if the danger is in the spread of networks of power and control through the devices of global capitalism — whether or not they are stitched as appendages to a modicum of democracy — the task of isolating, much less controlling empire, is tricky indeed. Slavoj Žižeck has pointed out that despite the tendency to dismiss Fukuyama's claim of the "end of history" as characterizing the rise of liberal democracy in the wake of the Soviet Union collapse, we have come to assume this very position. That is to say, “...nobody asks the question, 'Will 
capitalism stay? Will States stay?' We basically accept the frame"

(Democracy Now, 2008). Ultimately, the R2P passes on this question. Whether or not this is prudent for the long-term reduction of violent conflict should be considered as a suggestion for further research.

Finally, a last objection to the responsibility to protect regards the imbalance of international power when applying protection elements to R2P type crimes. The challenge or impossibility in holding powerful nations accountable, who do not consent to a peacekeeping force, seems to be at first glance, an obstacle in meeting the international responsibility to protect. In other words, it's hypocritical to expect some countries to submit to the authority of the Security Council and the UN, while others may pick and choose what to follow, as the U.S. did in the case of Nicaragua.

There are two responses to this argument, both of which recognize the value of finding the best-case scenario in less than ideal realities. The first is straightforward: the reality of international power difference does not and should not prevent the development and improvement of life-saving response criteria to humanitarian crises. The reality of power difference does not condemn us to international nihilism. Just because the international community is unable to intervene everywhere in the world, does not mean that it cannot or should not, intervene anywhere in the world. The second response recognizes that, limited though they might be, there are exist actions recommended by the R2P that can be taken even against powerful and defiant states. As Gareth Evans, co-chair of 
the ICISS points out, "[n]o major country in the world, however big and powerful, is today wholly immune from peer group pressure" (Evans, 2008, p. 293).

The future role of the R2P, as an impetus for consensus building between the non-intervention/protection conflict, appears to be continuing in the immediate future. During a 2009 debate over future of the R2P in the General Assembly, the melt-down that was perceived imminent following the objections during the appointment of the special advisor, failed to materialize. The result was that the body endorsed the continued exploration of the R2P concept. Likening the R2P to the Universal Declaration of Human Rights as a focus for the organization of efforts around a particular theme, Noam Chomsky pointed out that the contributions of the responsibility to protect, "with sufficient commitment... could be significant indeed" (Chomsky, 2009).

Darfur and the R2P

While there were many mistakes made in the response to Darfur there were positive signs as well. Failures from May 2003 onwards stemmed from a lack of political will and cohesion, particularly in the Security Council, and the near absence of prevention efforts preceding the outbreak of violence. They included a focus on the North-South peace process over Darfur and its exclusion from the CPA agreements, the lack of multilateral pressure, insufficient support for the AU observers, and allowing the GoS to continually renege on its 
commitments to the international community, as it cited sovereignty in order to prevent the deployment of UN peacekeepers (Srinivasan, 2006).

On the other hand, the involvement of the AU as an alternative to UN peacekeepers, and the (albeit limited) positive impact it achieved during its first observer mission, set the stage for its continued involvement in future conflicts in Africa, and did take the first steps towards establishing security in the region leading the way for UN involvement.

The deadlock that the AU was able to penetrate stemmed from objections by Khartoum against UN peacekeepers, as well as the findings of a 2004 "mini summit" in Tripoli, led by Libya and Egypt, that rejected "any foreign intervention by any country whatsoever in this pure African issue" (Libyan Jamahiriya Broadcasting Corporation, 2004).

The lack of unity from China and Russia in the Security Council for the application of pressure towards greater UN involvement contributed to the slow and indecisive response. Resolution 1556 in 2004, which demanded (unsuccessfully) that the Sudan disarm the Janjaweed and endorsed the AU deployment of monitors, passed only from China's abstention. Later, under the threat of a veto, China joined with Russia in abstaining from resolution 1706 which, under China's insistence of wording, "invited the consent" of Khartoum to allow the expansion of the southern UN presence into Darfur (Reeves, 2007). China's motivation for doing so, as a result of its close relationship with Sudan through oil and development contracts, has been well established (Apsel, 
2009; Straus, 2005; Bellamy \& Williams, 2006). As a signal of support to Khartoum, it also sent a government delegate in 2007 to survey a number of IDP camps in Darfur, returning with findings that "humanitarian conditions were generally fine and that security was improving, especially since the signing of the Darfur Peace Agreement" (Reeves, 2007).

The lack of unity in pressuring Sudan, the watering-down of resolutions in order to prevent them from being vetoed, and the underfunding of the $\mathrm{AU}$, demonstrated clearly to the government that the threats of the international community were empty, and gave Khartoum the correct impression that it could continue to as it wished. As Nathan (2007) points out, "the approach adopted in relation to Darfur where the international community issued threats and then failed to consistently act on them, emboldened the belligerents" (p.265).

Eventually, after international pressure focused on China as being partially responsible for allowing the situation to continue, including the cancellation of an appearance by Stephen Spielberg during the opening ceremony of the Olympics, it joined with the rest of the Security Council in authorizing the hybrid AU/UN mission with resolution 1769. In so doing, Sudan acquiesced to the deployment of UN peacekeepers.

The lapse of nearly a year and a half between the outbreak of violence and the first AU observers in Darfur, which also corresponded with the highest number of deaths during the conflict, was likely the most egregious failure in the international response(Reeves, 2007; De Waal, 2007). Presumably under 
unanimous international pressure, the UN would have become involved much earlier as evidenced by their actions once resolution 1769 passed. If not, unanimous international pressure may have secured a broader mandate or adequate support for the $\mathrm{AU}$ towards stopping imminent attacks during the counter-insurgency.

Given the lack of cooperation from Russia and China, the authorization of the initial AU mission demonstrates the value of increased participation of international organizations, as recognized by the R2P. The fact that a poorly designed, ill-equipped, and underfunded observation force was able to reduce violent deaths in Darfur suggests that a properly conducted one could have saved that many more lives.

The lack of political will within the Security Council to enact early and enforceable resolutions against the Al-Bashir government for the protection of Darfurians highlights the importance of a "code of conduct" against the threat or use of veto. The call for a "uniting for peace" procedure in the General Assembly, even if it failed to pass, might have also rallied support for greater UN involvement and put pressure on countries abstaining from Security Council resolutions.

Accompanying the lack of political will was a widespread failure of early warning and prevention systems preceding the outbreak of violence in Darfur. Despite reports from NGOs throughout the 90's that the tensions between ethnic groups were increasing, only two UN development programs were active in the 
region between 1992 and 2001 (Srinivasan, 2006). Paradoxically, in 2003 following a report from the Office of the High Commissioner for Human Rights expressing concern for the worsening situation, Sudan was removed from the watch list of the Commission on Human Rights and special rappertours were pulled out (Srinivasan, 2006). Combined with international unwillingness to view Darfur and the north/south peace process as connected, or address them in unison, the few warning signs that did exist were muted or ignored, ultimately preventing a timely reaction following the outbreak of violence.

While there are many difficulties in establishing conflict prevention mechanisms, including predicting which tensions are most likely to escalate into open conflict in allocating resources, and determining the effectiveness of measures taken, (Wallensteen, 2007) Darfur lacked even moderate prevention measures.

It's worth noting that while native tribal conflict resolution does exist, and is often used in the native administrations of rural Darfur, it has traditionally been used to address local land disputes and small-scale conflicts within the community. As Abdul-Jalil, Mohammed, \& Yousuf (2007) point out, these native administrators were often exploited by younger, educated politicans who sought to polorize ethnic tensions for their political gain (p.66).

The importance of early warning is repeatedly emphasized in the R2P, and was also among the specific recommendations in the 2005 outcome document. If prevention is the single most important element of the responsibility to protect, 
then early warning is among the most important elements of the responsibility to prevent. These failures in Darfur seem to echo the need for the ICISS recommendations of a centralized agency to collect and aggregate early warning information for emerging conflicts, and sound the alarm when situations begin to turn violent.

Perhaps most importantly, the unwillingness of the international community to challenge Sudan's sovereignty following its loud and frequent objections to a UN peacekeeping mission, combined with the numbers of dead, wounded, and displaced shows that Darfur can be described as a manifest example of the basic conflict between non-intervention and protection. Failure of the R2P?

The case of Darfur illustrates that the present response framework for R2P type crimes remains insufficient. It further demonstrates the importance of consensus building in the conflict between sovereignty and protection. Finally, it shows that the recommendations of the ICISS were not invoked against Sudan during the height of the killings. If the number of dead, displaced, and abused is any indication, the international response to Darfur was a failure.

That the international community did not violate the sovereignty of Darfur upheld the norm of non-intervention. That so many people died preventable deaths early in the conflict was a failure of protection. This may lead one to view Darfur as illustrating a failure of the R2P, yet this appears to be premature for a number of reasons. 
First, the R2P achieved affirmation and adoption in the 2005 world summit around the same time that the AU had been able to marginally improve death rates in Sudan. Considering that the R2P is essentially a collection of recommendations for the UN that attempt to improve its overall response for large-scale violent conflict, and not a legal treaty or convention, its implementation cannot be expected to happen in such a short amount of time. Immediately following the world summit vote, the R2P had hardly been given a chance to work its way into the procedures of the world body, not to mention survive the subsequent pushback following the world summit adoption.

Second, Darfur would illustrate a failure of the R2P if its conditions for success were based on deploying troops into conflict zones as soon as possible. As we have seen, the R2P works on a much deeper level, and represents an attempt to reconcile protection with the existing norms of non-intervention and international law.

Third, one case is an insufficient indicator of the success or failure of the responsibility to protect. As the $\mathrm{R} 2 \mathrm{P}$ is largely about reframing the debate and working towards consensus building, its impact will most likely be seen through a number of cases, should it manifest at all.

Darfur was certainly not an example of the R2P principles in action. Sudan not only failed in its responsibility to protect its population, but actively contributed in their suffering. Sudan exploited the concept of sovereignty with the help from China and their use of tactical accommodation in order to stall and 
misdirect the international community to continue their disastrous policies relatively unabated. Darfur was a perfect example of the necessity of further consensus and was a prime candidate for the recommendations of the ICISS, but unfortunately saw very few of them applied.

Even so, a forceful unilateral or multilateral military intervention in Darfur without Security Council approval, in the largest country in Africa, lacking an underlying peace process, at the closing end of a civil war, and in spite of efforts by the AU, would very likely have been equally disastrous. The function of peacekeepers is to support a peace agreement or ceasefire, and as De Waal (2007) points out, the "efforts to obtain a peace agreement and efforts to bring UN troops to Darfur cancelled each other out" (p.381).

Cohesion in the international community, particularly in the Security Council, would have been a start. If it had existed, the forceful imposition of a nofly zone in the areas where the government employed the use of helicopters and airplanes to bomb villages, or at least providing the $\mathrm{AU}$ with aerial defense capabilities would have disrupted the aerial coordination of attacks between the government and the Janjaweed, and halted bombing campaigns. Improved early warning systems to identify the emerging violence would have allowed mediators to work towards easing tensions, while greater support for economic development programs and peace-building initiatives would have opened further channels for dialogue between Arab and African groups. More concerted international pressure focused through the UN when violence did break out, and 
the calling for a "uniting for peace" procedure or a greater use of existing rapid response teams to augment the $\mathrm{AU}$ team, could have improved ceasefire monitoring efforts.

Examples of such measures in action can be seen in the 2008 post election unrest in Kenya, which has been cited as one example where swift prevention measures were taken to deescalate tensions and save lives (Brown, 2009). Talks mediated by Kofi Annan, the involvement of a unified Security Council which voted for a swift resolution to the conflict mere weeks following the outbreak of violence, along with swift criminal charges for police brutality and a targeted travel ban imposed by the United States helped in reducing violence, and led to a power sharing agreement between the opposing parties (BBC, 2008). When international political will comes together in agreement towards a common goal, the effect can be dramatic.

Consensus building in a conflict between the nature of state sovereignty may not entirely satisfy the understandable impulse of taking action when people are dying in the midst of violent conflict. However in conflict resolution, consensus building is a necessary first step, and just as important in determining what outcomes can ultimately be agreed upon. It is in this context that I believe the underlying objectives of the responsibility to protect become the most explicit. 
Conclusion

In brief, the non-intervention/protection conflict has not been solved by the emergence of the Responsibility to Protect. The importance of working towards consensus however to give meaning to the phrase "never again," could not be clearer.

Fisher \& Ury (1981) point out "as more attention is paid to positions, less attention is devoted to meeting the underlying concerns of the parties. Agreement becomes less likely" (p.5). Arguments for a right to humanitarian intervention assume positions, rather than interests. "We demand the right to protect suffering peoples," says one side, "We demand the right to autonomy and non-interference," says the other. Meanwhile, intervention either goes forward breaking laws and destroying any existing channels of dialogue, or individuals suffer and die while no action is taken.

The R2P tore a page directly from Fisher \& Ury's playbook. Protection is an interest, not a position. It can be filled many different ways, and stands for something much larger than the narrow concept of the right to humanitarian intervention. Most importantly, it serves to foster dialogue and real negotiation among the international community, a dialogue that continues to find willing participants in the large majority of states.

Among the largest outstanding issues to be discussed are the very practical questions of improving the rules of force within the Security Council. For example, if a code of conduct were established for R2P type crimes, under 
what criteria should force, or the threat of it, be allowed when the P5 are in agreement?

One suggestion for further research might be the use of tit for tat as the strategy activated when R2P crimes are identified and action deemed necessary. Tit for tat is a negotiation strategy and the most successful approach to solving the prisoner's dilemma that emphasizes cooperation with the other party at first, matches uncooperative behavior in kind, and reverts again to cooperation when the other party shows willingness (Axelrod, 1984).

Once the Security Council deems that a R2P type situation exists, tit for tat could then be used to include the full range of diplomatic measures from both cooperative, and punitive standpoints. Sanctions or development aid, travel restrictions or greater political recognition could all be included in the process of negotiation, and tit for tat strategy could potentially mitigate stall tactics and subterfuge, while also leaving the door for cooperation always open.

Additionally, a focus on meeting basic human needs, combined with the structural peace building concepts found in the R2P could serve to guide prevention and rebuilding efforts. The drive to meet basic psychological and physiological needs, and the resulting frustration when such needs remain unmet, often leads to certain response processes which make violence much more likely.

The need for identity, for example, has lead to the "increased identification by people with their group in difficult times [and] is evident in many ethnic 
conflicts and genocides" (Staub, 2003, p. 54). Recognizing the lack of these underlying needs, especially with perpetrators of egregious instances of violence, will lead to a deeper understanding of the root causes for the emergence of such violence in the first place, and inform and guide prevention efforts as recommended by the R2P. Developing societies around the satisfaction of basic human needs should be the normative goal in rebuilding and development efforts, and with the assistance of early warning systems, could ultimately diminish the number of cases that eventually meet the designation of R2P type crimes. Due to the intractable nature of the basic conflict between protection and non-intervention, maximizing such prevention efforts would effectively bypass many of contentious obstacles in the debate.

Still, the process of implementing the R2P, and determining when sufficient consensus exists, are important questions in their own right. Accomplishing such tasks cannot guarantee the prevention or swift cessation of future atrocities. However, given the momentum the R2P has already achieved, and the potential it contains for achieving consensus, continuing the dialogue under its guidance appears to be the best alternative at the moment. 


\section{References}

Abass, A. (2007). The United Nations, the African Union and the Darfur Crisis: Of Apology and Utopia. Netherlands International Law Review (54), 434-435.

Abdul-Jalil, M. A., Mohammed, A. A., \& Yousuf, A. A. (2007). Native Administration and Local Governance in Darfur: Past and Future. In A. De Waal (Ed.), War in Darfur and the Search for Peace (pp. 39-67). Cambridge: Global Equity Initiative.

African Union. (2002). The Constitutive Act. Retrieved May 01, 2010, from http://www.africa-union.org/About_AU/Constitutive_Act.htm

Amnesty Internatinal. (2004). Sudan, Darfur: Rape as a Weapon of War. London.

Annan, K. (2000, November 21). Military Operations Should Not Be Described as Humanitarian Action, Secretary-General Tells Symposium. Retrieved May 20, 2010, from http://www.unis.unvienna.org/unis/pressrels/2000/sg2723.html

Apsel, J. (2009). The Complexity of Destruction in Darfur: Historical Processes and Regional Dynamics. Hum Rights Rev , 10 (2), 239-259.

Arab Gathering Letter. (1987, Oct). Retrieved Mar 14, 2010, from http://www.aegistrust.org/Darfur-documents/arab-gathering-letter-1987.html

Atack, I. (2002). Ethical Objections to Humanitarian Intervention. Security Dialogue , 33 (3), 279-292.

Axelrod, R. (1984). The Evolution of Cooperation. New York: Basic Books.

Bacevich, A. J. (2002). American Empire: the realities and cosequences of U.S. diplomacy. Cambridge , Mass: Harvard University Press.

Badescu, C., \& Bergholm, L. (2009). The Responsibility To Protect and the Conflict in Darfur: The Big Let-Down. Security Dialogue , 40 (3), 287.

Badescu, C., \& Weiss, T. (2010). Misrepresenting R2P and Advancing Norms: An Alternative Spiral?

BBC. (2008, December 18). Rwanda: How the genocide happened . Retrieved May 20, 2010, from http://news.bbc.co.uk/2/hi/africa/1288230.stm

BBC. (2010, February 3). Analysis: Defining genocide . Retrieved May 21, 2010, from http://news.bbc.co.uk/2/hi/africa/3853157.stm

BBC. (2008, Februrary 7). Murder charges for Kenya police. Retrieved April 20, 2010, from http://news.bbc.co.uk/2/hi/africa/7232372.stm 
Bellamy, A. (2008). Conflict Prevention and the Responsibility to Protect. Global Governance, 14, 135-156.

Bellamy, A. (2004). Motives, outcomes, intent and the legitimacy of humanitarian intervention. Journal of military ethics , 3 (3), 216-232.

Bellamy, A. (2008, Dec 31). The Responsibility to Protect and the problem of military intervention. International Affairs .

Bellamy, A., \& Williams, P. (2006). The UN Security Council and the Question of Humanitarian Intervention in Darfur. Journal of Military Ethics , 5 (2), 144-160.

Bercovitch, J., \& Jackson, R. (2009). Conflict Resolution in the Twenty-first Century. Ann Arbor: The University of Michigan Press.

Berdal, M. R., \& Economides, S. (2007). United Nations interventionism: 1991 2004. Cambridge: Cambridge University Press.

Bock, C. W., \& Miller, L. R. (2004, December 9). Darfur: Where is Europe. The Washington Post , p. A33.

Bodin, J. (1992). On Sovereignty. New York: Cambridge University Press.

Brown, S. (2009). Donor responses to the 2008 Kenyan crisis: Finally getting it right? .Journal of Contemporary African Studies , 27 (3), 389-406.

Bull, H. (1977). The Anarchical Society. New York: Columbia University Press.

Bumiller, E. (2002, September 7). TRACES OF TERROR: THE STRATEGY; Bush Aides Set Strategy to Sell Policy on Iraq. Retrieved May 23, 2010, from New York Times: http://www.nytimes.com/2002/09/07/us/traces-of-terror-the-strategybush-aides-set-strategy-to-sell-policy-on-iraq.html

Bush, G. W. (2002, September 12). President Bush's address to the United Nations. Retrieved March 21, 2010, from CNN: http://transcripts.cnn.com/2002/US/09/12/bush.transcript/

Byers, M., \& Chesterman, S. (2003). Changing the rules about rules? Unilateral humanitarian intervention and the future of international law. In J. Holzgrefe, \& R. O. Keohane (Eds.), Humanitarian Intervention: Ethical, Legal, and Political Dilemmas (pp. 177-203). Cambridge: Cambridge University Press.

Chandler, D. (2001). The Road to Military Humanitarianism: How the Human Rights NGOs Shaped a New Humanitarian Agenda. Human Rights Quarterly, 23 (3), 678-700. 
Charter of the United Nations. (2006). New York: United Nations Department of Public Information.

Chesterman, S. (2001). Just War or Just Peace? Humanitarian intervention and international law. Oxford: Oxford University Press.

Chomsky, N. (2009). Statement by Professor Noam Chomsky. United Nations General Assembly Thematic Dialogue on the Responsibility to Protect. New York: United Nations.

Cohen, J. L. (2004). Whose Sovereignty? Empire versus International Law. Ethics \& International Affairs , 18 (3), 1-25.

Cohen, R., \& Deng, F. M. (1998). Masses in Flight: The global crisis of internal displacement. Washington D.C.: The Brookings Institution.

Convention on the Prevention and Punishment of the Crime of Genocide. (1948, December 9). Retrieved May 20, 2010, from http://www.un.org/millennium/law/iv-1.htm

Cortright, D., \& Lopez, G. (2002). Smart sanctions : targeting economic statecraft. Lanham, Md: Rowman \& Littlefield Publishers.

Dallmayr, F. R. (2005). Small wonder: global power and its discontents. Lanham, Maryland: Rowman \& Littlefield Publishers.

Daly, M. (2007). Darfur's Sorrow: A history of destruction and genocide. New York: Cambridge University Press.

De Jouvenel, B. (1957). Sovereignty: An inquiry into the political good. London: Cambridge University Press.

De Waal, A. (2007). Darfur's Elusive Peace. In A. De Waal (Ed.), War in Darfur and the Search for Peace (pp. 367-388). Global Equity Initiave, Harvard University.

Degomme, 0., \& Guha-Sapir, D. (2010). Patterns of mortality rates in Darfur conflict. The Lancet , 375 (9711), 294-300.

Democracy Now. (2008, Mar 11). Everybody in the World Except US Citizens Should Be Allowed to Vote and Elect the American Government. Retrieved May 18, 2010, from Democracy Now:

http://www.democracynow.org/2008/3/11/everybody_in_the_world_except_us

Department of Defense. (2008). BASE STRUCTURE REPORT FISCAL YEAR 2008

BASELINE. Retrieved April 05, 2010, from

www.acq.osd.mil/ie/download/bsr/BSR2008Baseline.pdf 
Doornbos, P. (1988). On Becoming Sudanese. In T. Barnett, \& A. Abdelkarim (Eds.), Sudan : state, capital, and transformation. London: Croom Helm.

Evans, G. (2008). The Responsibility to Protect: An Idea Whose Time Has Come ... and Gone? International Relations , 22 (3), 283-298.

Fadul, A.-J., \& Tanner, V. (2007). Darfur after Abuja: A View from the Ground. In A. De Waal (Ed.), War in Darfur and the Search for Peace (pp. 285-313). Global Equity Initiative, Harvard University.

Farer, T. J. (2003). Humanitarian Intervention Before and After 9/11. In J. Holzgrefe, \& R. O.Keohane (Eds.), Humanitarian Intervention: Ethical, Legal, and Political Dilemmas (pp. 53-89). Cambridge: Cambridge University Press.

Feinstein International Famine Center. (2005). Darfur - Livelihoods under Siege. Medford: Tufts University.

Feinstein, L., \& Slaughter, A.-M. (2004). A Duty to Prevent. Foreign Affairs , 83 (1), 136-150.

Filkins, D. (2010, February 12). Afgan Offensive Is New War Model. New York Times .

Finnemore, M. (2003). The Purpose of Intervention. Ithaca: Cornell University Press.

Fiona, T. (2002). Condemned to Repeat? The paradox of humanitarian action. Ithaca: Cornell University Press.

Fisher, R., \& Ury, W. (1981). Getting to Yes: Negotiating Agreement Without Giving In. Boston: Houghton Mifflin Company.

Flint, J. (2007). Darfur's Armed Movements. In A. De Waal (Ed.), War in Darfur and the Search for Peace (pp. 140-172). Global Equity Initiative, Harvard University.

Flint, J., \& De Waal, A. (2005). Darfur: A short history to a long war. New York: Zed Books.

Franck, T. (1992). The Emerging Right to Democratic Governance. Americna Journal of International Law , 86 (1), 46-91.

Frontline. (2006, Feburary 21). Frontline: the insurgency: transcript. Retrieved May 07, 2010, from http://www.pbs.org/wgbh/pages/frontline/insurgency/etc/script.html 
Glennon, M. J. (2001). Limits of Law, Perogatives of Power: Interventionism after Kosovo. New York: Palgrave.

Goldstein, J., Kahler, M., Keohane, R., \& Slaughter, A.-M. (2003). Introduction: Legalization and world politics. International Organization, 54 (03), 385-399.

Hagan, J., \& Rymond-Richmond, W. (2009). Darfur and the Crime of Genocide. New York: Cambridge University Press.

Haggar, A. (2007). The Origins and Organization of the Janjawiid in Darfur. In A. De Waal (Ed.), War in Darfur and the Search for Peace (pp. 113-139). Global Equity Initiative, Harvard University.

Hardin, G. (1968). The Tragedy of the Commons. Science, 162 (3859), 1243-1248.

Hardt, M., \& Negri, A. (2000). Empire. Cambridge, Mass: Harvard University Press.

Hayman, P., \& Williams, J. (2006). Westphalian sovereignty: rights, intervention, meaning and context. Global society. , 20 (4), 521-542.

High-Level Panel on Threats, Challenges and Change. (2004, December 2). A More Secure World: Our shared responsbility. Retrieved May 20, 2010, from http://www.un.org/secureworld/

Hinsley, F. (1966). Sovereignty. New York: Basic Books, INC.

Hoge, W. (2004, July 30). U.N. Calls for Sudan to Halt Attacks by Militias. New York Times .

Holzgrefe, J., \& Keohane, R. O. (2003). Humitarian Intervention: Ethical, Legal, and Political Dilemmas. Cambridge: Cabridge University Press.

Human Rights Watch. (2005, December 8). Entrenching Impunity. Retrieved May 21, 2010, from http://www.hrw.org/reports/2005/darfur1205/

Human Security Center. (2005). Human Security Report, 2005: War and Peace in the Twenty-First Century. New York: Oxford University Press.

ICISS. (2001). The Responsiblity to Protect. International Commission on Intervention and State Sovereignty, Ottawa.

International Commission of Inquiry on Darfur. (2005, January 25). Retrieved May 21, 2010, from www.un.org/News/dh/sudan/com_inq_darfur.pdf

International Court of Justice. (1986). International Court of Justice Cases. Retrieved May 20, 2010, from http://www.icj-cij.org/docket/index.php?p1=3 
International Criminal Court. (2010, Mar 01). Sitiations and Cases. Retrieved May 11, 2010, from http://www.icc-cpi.int/Menus/ICC/Situations+and+Cases/

International Criminal Court. (2009, Mar 4). Warrant of Arrest for Omar Hassan Ahmad Al Bashir. Retrieved May 21, 2010, from www.icccpi.int/iccdocs/doc/doc639078.pdf

International Crisis Group. (2007, November 26). Darfur's New Security Reality. Retrieved May 21, 2010, from http://www.crisisgroup.org/en/publicationtype/media-releases/2007/africa/darfurs-new-security-reality.aspx

International Displacement Monitoring Centre. (2008). Internal Displacement: Global Overview of Trends and Developments in 2008. Geneva: International Displacement Monitoring Centre.

Iyob, R., \& Khadiagala, G. (2006). Sudan: The illusvie quest for peace. London: Lynne Reinner Publishers.

Jackson, R. (2000). The Global Covenant: Human Conduct in a World of States. Oxford: Oxford University Press.

Johnson, C. (2004). The Sorrows of Empire. London: Verso.

Kazmin, A., \& Lynch, C. (2008, May 8). Scant Aid Reaching Burma's Delta. Retrieved May 13, 2010, from The Washington Post: http://www.washingtonpost.com/wpdyn/content/article/2008/05/07/AR2008050700642.html

Kebbede, G. (1999). Sudan's Predicament: Civil War, Displacement, and ecological degradation. Hampshire, England: Ashgate Publishing Limited.

Keohane, R. O. (2003). Political Authority after Intervention: Gradations in Sovereignty. In J. Holzgrefe, \& R. O. Keohane (Eds.), Humanitarian Intervention: Ethical, Legal, and Political Dilemmas. Cambridge: Cambridge University Press.

Kiernan, B. (2007). Blood and soil: a world history of genocide and extermination from Sparta to Darfur. Harrisonburg, Virgina: RR Donnelley.

Knudsen, T. (2002). The English School of International Relations and the International Society Approach. In K. Imbusch, \& K. Segbers (Eds.), International Relations Online. Berlin: Free University of Berlin.

Krasner, S. D. (1999). Sovereignty: Organized Hypcrisy. Princeton: Princeton University Press.

Langholtz, H. (1998). The Evolving Psychology of Peacekeeping. In H. Langholtz (Ed.), The Psychology of Peacekeeping (pp. 4-15). Westport, CT: Praeger. 
Libyan Jamahiriya Broadcasting Corporation. (2004, October 18). African mini Summit on Darfur wound up in Libya. Retrieved May 23, 2010, from ReliefWeb: http://ocha-gwapps1.unog.ch/rw/rwb.nsf/db900sid/EVIU65WF2Z?OpenDocument\&Click=

Mamdani, M. (2009). Saviors and Survivors: Darfur, politics, and the War on terror. New York: Pantheon Books.

Mill, J. S. (1859). A Few Words on Non-Intervention. Foreign Policy Perspectives, 8.

Murphy, S. D. (1996). Humanitarian Intervention: The United Nations in an evolving world order. Philadelphia: University of Pennsylvania Press.

Nanda, V. P. (1990). The Validity of United States Intervention in Panama under International Law . The American Journal of International Law , 84 (2), 494-503.

Nathan, L. (2007). The Making and Unmaking of the Dafur Peace Agreement. In A. De Waal (Ed.), War in Darfur and the Search for Peace (pp. 245-266). Global Equity Initiative, Harvard University.

Natsios, A. (2007, Feburary 8). The President's Special Envoy to Sudan House Committee on Foreign Affairs. Retrieved May 21, 2010, from http://foreignaffairs.house.gov/110/nat020807.htm

New York Times. (1992, July 15). The Well-Fed Dead in Bosnia.

New York Times. (2005, March 16). U.N. now estimates 180,000 dead in Sudan.

Newey, G. (2008). Routledge philosophy guidebook to Hobbes and Leviathan. New York: Routledge.

Newman, M. (2009, Dec 31). Revisiting the Responsibility to Protect. The Political Quarterly.

OCHA. (2008, October). UNICEF Darfur Overview. Retrieved March 1, 2010, from http://www.unicef.org/infobycountry/sudan_darfuroverview.html

O'Fahey, R. (2008). The Darfur Sultanate: A history. New York: Columbia University Press.

Orbinski, J. (1999, December). Médecins Sans Frontières Nobel Lecture. Retrieved May 20, 2010, from http://nobelprize.org/nobel_prizes/peace/laureates/1999/msf-lecture.html 
Organization of American States. (1967). Charter of the Organization of American States. Retrieved May 01, 2010, from http://www.oas.org/dil/treaties_A41_Charter_of_the_Organization_of_American_States.htm

Polgreen, L. (2007). Peacekeepers as Targets: Darfur Attack Imperils Talks. New York Times , 2010 (May), 21.

Powell, C. (2001, October 26). Remarks to the National Foreign Policy Conference for Leaders of Nongovernmental Organizations. Retrieved May 20, 2010, from http://avalon.law.yale.edu/sept11/powell_brief31.asp

Prunier, G. (2008). Darfur: A 21st century genocide (3rd Edition ed.). Ithaca: Cornell University Press.

Ramsey, P. (1983). The Just War: Force and Political Responsbility. Cumnor Hill, Oxford: Rowman \& Littlefield Publishers.

Reeves, E. (2007). Genocide Without End? Dissent, Summer, 1-6.

Refugees International. $(2005,11$ 09). No Power to Protect: The African Union Mission in Sudan. Retrieved May 21, 2010, from http://www.refugeesinternational.org/policy/in-depth-report/no-powerprotect-african-union-mission-sudan

Report of the Secretary General. (1992, June 17). An Agenda for Peace Preventive diplomacy, peacemaking and peace-keeping. Retrieved May 20, 2010, from http://www.un.org/Docs/SG/agpeace.html

Report of the Secretary-General and the Chairperson of the African Union Commission. (2007, June 5). UNAMID African Union/United Nations Hybrid operation in Darfur. Retrieved May 21, 2010, from http://www.un.org/en/peacekeeping/missions/unamid/mandate.shtml

Report of the Secretary-General on the work of the Organization. (2000, August 30). Millenium Report of the Secretary General. Retrieved May 21, 2010, from http://www.un.org/millennium/sg/report/

Report of the Secretary-General. (1998, April). The causes of conflict and the promotion of durable peace and sustainable development in Africa. Retrieved Mar 5, 2010, from http://www.un.org/ecosocdev/geninfo/afrec/sgreport/report.htm

Reuters. (2010, Feburary 25). Darfur rebels say attacked by army, war not over. Retrieved Mar 15, 2010, from http://www.reuters.com/article/idUSTRE61N55U20100225 
Schacter, O. (1984). The Legality of Pro-Democratic Invasion. American Journal of International Law , 78 (3), 645-650.

Scheuerman, W. E. (2007). Carl Schmitt and Hans Morgenthau: Realism and beyond. In M. C. Williams, Realism Reconsidered: The Legacy of Hans J. Morgenthau in International Relations. Oxford: Oxford University Press.

Schmitt, C. (1996). The Concept of the Political. (G. Schwab, Trans.) Chicago: University of Chicago Press.

Seekers of Truth and Justice. (2004, March). The Black Book: Imbalance of Power and Wealth in Sudan. Retrieved May 20, 2010, from http://www.sudanjem.com/2004/sudanalt/english/books/blackbook_part1/book_part1.asp.htm

Sens, A. G. (1997). Somalia and the Changing Nature of Peacekeeping: the implications for Canada. Ottowa: Public Works and Government Services Publishing.

Simons, M. (2001, August 3). TRIBUNAL IN HAGUE FINDS BOSNIA SERB GUILTY OF GENOCIDE. New York Times .

Srinivasan, S. (2006, September). Minority Rights, Early Warning and Conflict Prevention: Lessons from Darfur . Retrieved May 21, 2010, from Minority Rights Group International: www.minorityrights.org/download.php?id=102

Stankiewicz, W. (1969). Introductory. In W. Stankiewicz, In Defense of Sovereignty (pp. 3-38). New York: Oxford University Press.

Statute of the International Court of Justice. (2006). New York: United Nations Department of Public Information.

Staub, E. (2003). The Psychology of Good and Evil. Cambridge: Cambridge University Press.

Steidle, B. (2007). The Devil Came on Horseback: Bearing witness to the Genocide in Darfur. New York: Public Affairs.

Stein, M. (2004). Unauthorized humanitarian intervention. Social Philosophy and Policy , 21 (01), 14-38.

Steinberg, D. (2005, Oct 26). Orphans of Conflict Caring for the Internally Displaced. 1-20.

Sterling-Folker, J. (2006). English School Approaches. In J. Sterling-Folker (Ed.), Making Sense of International Relatons Theory (pp. 303-309). Boulder: Lynne Rienner Publishers, Inc. 
Straus, S. (2005). Darfur and the genocide debate. Foreign Affairs , 84 (1), 123-133.

Strauss, L. (1952). The political philosophy of Hobbes . Chicago: University of Chicago Press.

Sudanese Liberation Movement. (2003, Mar 14). SLM/SLA Political Declaration. Retrieved May 20, 2010, from http://www.sudan.net/news/press/postedr/214.shtml

Sutterlin, J. S. (2003). The United Nations and the Maintenance of International Security: A Challenge to be Met. Westport, CT: Praeger Publishers.

Tesón, F. R. (1988). Humanitarian Intervention: An inquiry into law and morality. Dobbs Ferry, New York: Transnational Publishers, INC.

Thakur, R. (2008, May 19). Crisis and Response. Retrieved June 10, 2009, from Yale Global Online: http://yaleglobal.yale.edu/display.article?id=10824

Thakur, R. (2005). Iraq and the Responsibility to Protect. Global Diolouge , 7.

Thakur, R. (2006). The United Nations, Peace and Security: From Collective Security to the Responsibility to Protect. Cambridge: Cambridge University Press.

The Seville Statement on Violence. (1986, May 16). UNESCO. Retrieved May 15, 2010, from www.unesco.org/cpp/uk/declarations/seville.pdf

Tubiana, J. (2007). Darfur: A War for Land? In A. De Waal (Ed.), War in Darfur and the Search for Peace (pp. 68-91). Global Equity Initiative.

U.N. General Assembly 62nd Sess. (2008, March 4). Sixty-second General Assembly Fifth Committee 28th Meeting. Retrieved May 5, 2010, from http://www.un.org/News/Press/docs/2008/gaab3837.doc.htm

U.N. General Assembly Res/20/2131. (1965, Dec 21). UN Documents. Retrieved June 07, 2010, from http://www.un-documents.net/a20r2131.htm

U.N. General Assembly Res/25/2625. (1970, Oct 24). UN Documents. Retrieved June 07, 2010, from http://www.un-documents.net/a25r2625.htm

U.N. General Assembly Res/5/377. (1950, November 3). Resolution 377 Uniting for Peace. Retrieved May 21, 2010, from www.un.org/depts/dhl/landmark/pdf/ares377e.pdf

U.N. General Assembly Res/55/281. (2001). Prevention of Armed Conflict - Report of the Secretary-General. Retrieved May 21, 2010, from http://www.reliefweb.int/library/documents/2001/un-conflprev-07jun.htm 
U.N. General Assembly Res/57/337. (2003, July 3). Prevention of Armed Conflict. Retrieved May 21, 2010, from http://www.undocuments.net/a57r337.htm

U.N. General Assembly Res/59/565. (2004, December 2). Report of the SecretaryGeneral's High-Level Panel. Retrieved May 21, 2010, from www.un.org/secureworld/report.pdf

U.N. General Assembly Res/60/1. (2005, September 20). 2005 World Summit Outcome. para. 139.

U.N. General Assembly Res/63/677. (2009, January 12). Implementing the responsibility to protect: Report of the Secretary-General. Retrieved May 21, 2010, from http://www.unhcr.org/refworld/docid/4989924d2.html

U.N. General Assembly, 55th Sess. (2000). Report of the Secretary-General on the work of the Organization. Supplement no. 1 (A/55/1) , para. 37.

U.N. News Centre. (2004, May 7). UN finds Sudan has carried out massive human rights violations in Darfur. Retrieved April 11, 2010, from http://www.un.org/apps/news/storyAr.asp?NewsID=10664\&Cr=sudan\&Cr1

U.N. Press Release. (1999, September 20). SECRETARY-GENERAL PRESENTS HIS ANNUAL REPORT TO GENERAL ASSEMBLY. Retrieved May 20, 2010, from http://www.un.org/News/Press/docs/1999/19990920.sgsm7136.html

U.N. Security Council. (2006, August 31). Resolution 1706. Retrieved May 21, 2010, from http://www.un.org/Docs/sc/unsc_resolutions06.htm

U.N. Security Council. (2007, July 31). Resolution 1769. Retrieved May 21, 2010, from http://www.un.org/Docs/sc/unsc_resolutions07.htm

U.N. Security Council. (2009, August 6). Resolution 1881. Retrieved May 21, 2010, from http://www.un.org/Docs/sc/unsc_resolutions09.htm

U.N. Security Council. (1992, Dec 3). Resolution 794 (S/RES/794). New York: United Nations.

U.S. Government Accountablity Office. (2006, November). Darfur Crisis: Death Estimates Demonstrates Severity of Crisis, but Their Accuracy and Credibility Could Be Enhanced.

UNAMID Facts and Figures. (2010, May 21). Retrieved May 21, 2010, from UNAMID African Union/United Nations Hybrid operation in Darfur: http://www.un.org/en/peacekeeping/missions/unamid/facts.shtml 
UNHCR. (2009). 2008 Global Trends: Refugees, Asylum-seekers, Returnees, Internally Displaced and Stateless Persons. UNHCR.

United Nations Department of Public Information. (1999, February 12). UNPREDEP Recent Developments. Retrieved May 4, 2010, from United Nations Peacekeeping Operations:

http://www.un.org/Depts/DPKO/Missions/unpred_r.htm

United Nations High Commissioner for Human Rights. (2004, May 3). Situation of human rights in the Darfur region of the Sudan. Retrieved May 21, 2010, from http://www.unhchr.ch/huridocda/huridoca.nsf/\%28Symbol\%29/E.CN.4.2005.3. En

United Nations Office for the Coordination of Humanitarian Affairs. (2009, January 1). Darfur Humanitarian Profile No. 34. Retrieved March 20, 2010, from http://ochaonline.un.org/sudan/SituationReports/DarfurHumanitarianNeedsPr ofile/tabid/3368/language/en-US/Default.aspx

United Nations Treaty Collection. (2010, May 11). Retrieved May 11, 2010, from Rome Statute of the International Criminal Court: http://treaties.un.org/Pages/ViewDetails.aspx?src=TREATY\&mtdsg_no=XVIII$10 \&$ chapter=18\&lang=en

United States Senate. (2007, April 11). Darfur: A 'Plan B' to Stop Genocide? Retrieved April 20, 2010, from U.S. Senate Committee on Foregin Relations: http://foreign.senate.gov/hearings/2007/hrg070411a.html

Wadlow, R. (2006). The Darfur Peace Agreement is not Peace. International Journal on World Peace, 23 (1), 1-3.

Wallensteen, P. (2007). Understanding Conflict Resolution (2nd Edition ed.). London: Sage Publications.

Wallensteen, P., \& Sollenberg, M. (2000). Armed Conflict: 1989 - 1999. Journal of Peace Research , 37 (4).

Weiss, T. (2007). Humanitarian Intervention: War and Conflict in the Modern World. Cambridge: Polity Press.

Williams, P. (2006). Military Responses to Mass Killing: The African Union mission in Sudan. International Peacekeeping , 13 (2), 168-183.

Zaum, D. (2007). The Sovereignty Paradox. New York: Oxford University Press.

Zuckert, C., \& Zuckert, M. (2006). The Truth about Leo Stauss. Chicago: University of Chicago Press. 